\title{
Protozoan infections in farmed fish from Brazil: diagnosis and pathogenesis
}

\author{
Infecçóes por protozoários em peixes cultivados no Brasil: diagnóstico e patogênese \\ Mauricio Laterça Martins ${ }^{1 *}$; Lucas Cardoso ${ }^{1}$; Natalia Marchiori²; Santiago Benites de Pádua ${ }^{3}$ \\ ${ }^{1}$ Laboratório de Sanidade de Organismos Aquáticos - AQUOS, Departamento de Aquicultura, Universidade Federal de Santa \\ Catarina - UFSC, Florianópolis, SC, Brasil \\ ${ }^{2}$ Empresa de Pesquisa Agropecuária e Extensão Rural de Santa Catarina - Epagri, Campo Experimental de Piscicultura de Camboriú, \\ Camboriú, SC, Brasil \\ ${ }^{3}$ Aquivet Saúde Aquática, São José do Rio Preto, SP, Brasil
}

Received January 19, 2015

Accepted February 2, 2015

\begin{abstract}
The Phylum Protozoa brings together several organisms evolutionarily different that may act as ecto or endoparasites of fishes over the world being responsible for diseases, which, in turn, may lead to economical and social impacts in different countries. Apart from the recent advances for the diagnosis of fish diseases in Brazil, little is known on the protozoan parasites and their relationship with environment and host. This revision presents the most important protozoan parasites found in farmed fish from Brazil, not only with emphasis on its diagnosis, biology, transmission and host-parasite relationship, but also on some information that may be useful to researchers in determining the correct diagnosis in fish farms.
\end{abstract}

Keywords: Fish parasites, disease, ciliate, dinoflagellate, pathogenicity.

\section{Resumo}

O filo Protozoa reúne diversos organismos evolutivamente distintos que podem atuar como ecto ou endoparasitos de peixes em todo o mundo, sendo responsáveis por doenças as quais, por sua vez, podem ocasionar impactos econômico e social nos diferentes países. Apesar dos recentes avanços no campo de diagnóstico de doenças em peixes no Brasil, ainda pouco se conhece sobre a fauna de protozoários parasitos de peixes e suas relaçóes com o ambiente e hospedeiro. Esta revisão apresenta os mais importantes protozoários parasitos encontrados em peixes cultivados no Brasil, não apenas com ênfase no seu diagnóstico, biologia, transmissão e relação hospedeiro-parasito, mas também algumas informaçóes que podem ser úteis para pesquisadores para o correto diagnóstico em pisciculturas.

Palavras-chave: Parasitos de peixes, enfermidade, ciliado, dinoflagelado, patogenicidade.

\section{Introduction}

The Phylum Protozoa gathers several organisms evolutionarily different that may act as ecto and endoparasites in fish (LOM \& DYKOVÁ, 1992), as well as in other vertebrates and also invertebrates. They are the causative agents of diseases in the global aquaculture causing, among other things, damage and reduced growth of the host fish (MORAES \& MARTINS, 2004), favoring secondary bacterial infections (XU et al., 2012) and mortality, all leading to constraints in global aquaculture production.

In this way, parasitic protozoan diseases are responsible not only for great losses to the commercial fishing industry, but also for a

*Corresponding author: Mauricio Laterça Martins, Aquatic Organism Health Laboratory - AQUOS, Aquaculture Department, Federal University of Santa Catarina - UFSC, Rod. Admar Gonzaga, 1346, CEP 88040-900, Florianópolis, SC, Brazil, e-mail: mauricio.martins@ufsc.br negative social impact in developing countries where aquaculture activities contribute to food production of high nutritional value to the needy population (BONDAD-REANTASO et al., 2005).

A number of prophylactic and curative measures have been suggested, although many of the recommended chemicals may be over-used or misused by aquacultural workers, leading to parasite's potential drug resistance and negative impact on the aquatic environment. In this way, it must be highlighted the importance of disease impact in order to elaborate efficient strategies for early diagnosis and fast intervention in management practices in fish farms so as to obtain a stable and sustainable production (PÁDUA \& CRUZ, 2014).

This revision presents the most important protozoan parasites found in farmed fish in Brazil, with emphasis on its diagnosis, 
distribution, biology, transmission routes and host-parasite relationship that may be useful to researchers in determining the correct diagnosis of fish pathogens.

\section{Ciliophora}

These unicellular protozoans possess mobile cilia involving the external body surface in some stage of their life cycle. Cytostome, macronucleous and micronucleous present. Reproduction by binary fission and conjugation. Apiosoma, Balantidium, Chilodonella, Epistylis, Ichthyophthirius multifiliis, Nyctotherus, Rhynchodinium paradoxum, Tetrahymena and Trichodinidae are the main representatives.

Apiosoma Blanchard, 1885

It comprises sessile peritrichid ciliated protozoans in the adult stage, with a conical body shape provided by contractile and nutritive vacuoles, infundibulum (oral cavity), scopula (from which the parasite attaches to host surface), peristomial disc, macronucleous and micronucleous (LI et al., 2008; EL-TANTAWY et al., 2013).

Like other sessile peritrichids such as Epistylis and Heteropolaria Foissner et Schubert, 1977, they use fish only for attachment and do not invade the epithelial cells, thus feeding by filtration of suspended material in the water. This phenomenon is termed epibiosis, in which the ciliate acts as epibiont and the host as basibiont (substrate organism) (PÁDUA et al., 2012b).

\section{Life cycle}

Apiosoma reproduces by binary fission and conjugation (LOM \& DYKOVÁ, 1992). Apart from these strategies, they can develop non-sessile forms denominated telotroch (free-swimming migratory stage which detaches from the parent colony in order to search for new hosts for attachment) in the water.

\section{Transmission}

It is transmitted by the free-swimming infective telotrochs.

\section{Diagnosis}

Microscopic examination of fresh-mounted scraps of fish's skin, fins and gills is the main technique for diagnosis of Apiosoma (Figure 1a,b). As the parasite presents a robust and long $(40-70 \mu \mathrm{m})$ body shape, it can be therefore easily diagnosed even in infections with low parasite densities. For a detailed view of the morphological features used for specific identification, the following staining techniques can be used: silver nitrate impregnation (Figure 1c), protargol and Giemsa (Figure 1d), Heidenhain, Ehrlich or Harris haematoxylin, as well as neutral red (LI et al., 2008). The main characteristics used for identification are body length and width; presence of scopula; body shape; position, length and width of
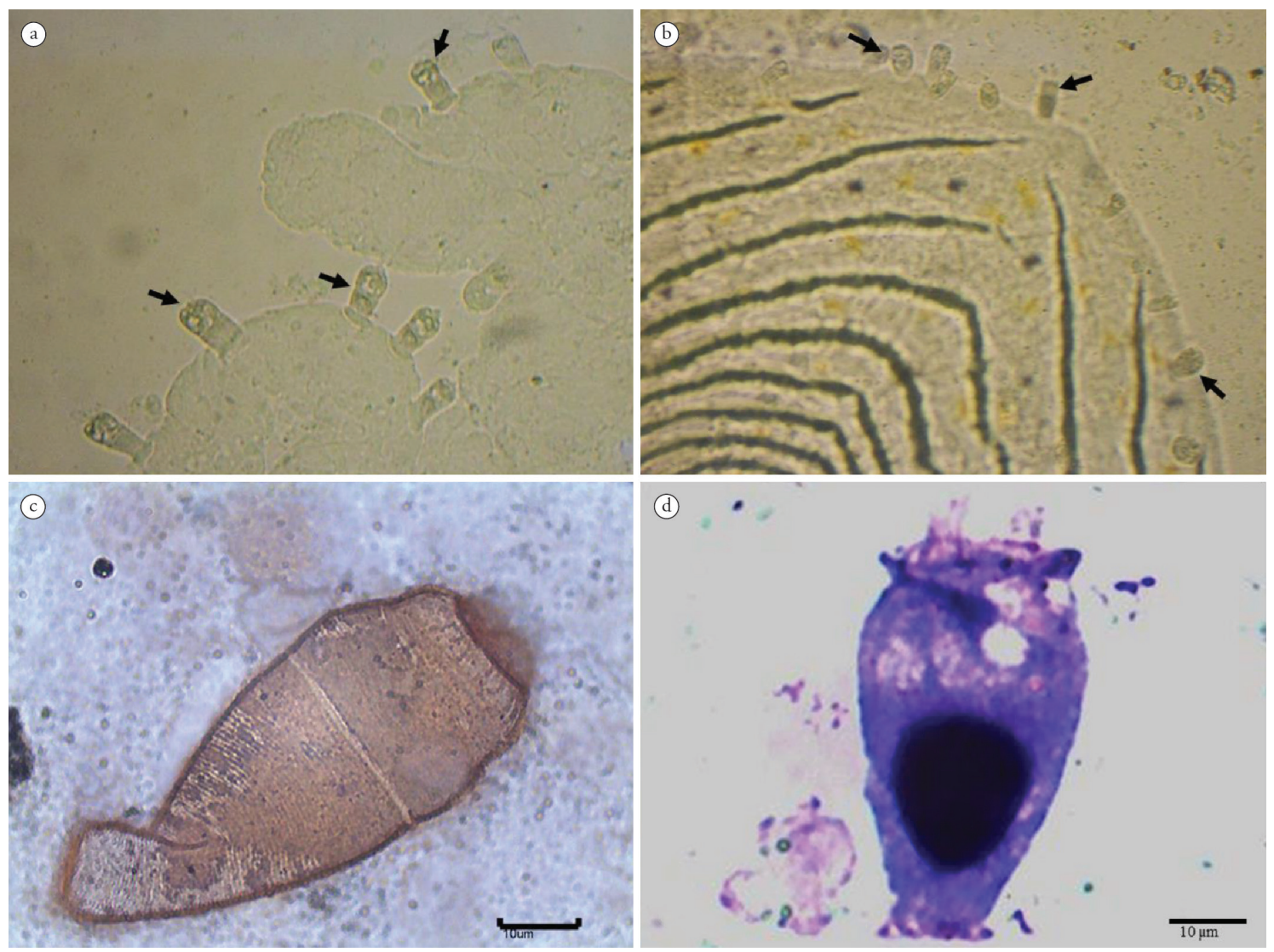

Figure 1. Apiosoma attached on the epithelium (a) and scale (b) of Nile tilapia larva Oreochromis niloticus in fresh-mounted slide. Silver nitrate impregnated specimen to observe the ciliary (c) and stained with Giemsa (d) showing the nuclear apparatus. 
macronucleus; micronucleus diameter; position of contractile vacuole; peristomial disc diameter and peduncle width (LI et al., 2008; EL-TANTAWY et al., 2013).

\section{Pathogenesis and clinical signs}

As the parasite attaches on the host by scopula and do not invade epithelial cells, the pathological alterations are discrete or even less evident. When heavily infested on the fish gills, however, these parasites cause reduced breathing surface to gas exchanges on the gills. In this case, fish will experience respiratory distress and may be seen near the surface of the water, gasping for air (DURBOROW, 2003). Differently, it was observed displacement of scales possibly due to secondary infections on tilapia fingerlings highly infested on the skin (PÁDUA, S.B. personal communication).

Clinical signs may be seen in diseased fish but are not specific and are frequently associated with respiratory difficulty and hyperventilation. Skin color alterations like darkness can also be observed. Li et al. (2008) detected loss of equilibrium, low swimming on the water surface and anorexia. As with most protozoans, environmental debasement and crowded conditions cause them to become more damaging (DURBOROW, 2003).

\section{Chilodonella Strand, 1926}

Leaf-shaped ciliated protozoans, oval, dorsoventrally flattened, slightly asymmetric (Figure 2a-c) and mobiles. Macro and micronucleus well evidenced (Figure 2c); the ventral surface has two longitudinal rows of ciliary kineties (Figure 2b,d) (PÁDUA et al., 2013a). Chilodonella species are free-living but some of them parasitize the skin, gills and fins of both freshwater, marine and estuary fish (PÁDUA et al., 2013a). Only two species have been observed causing damage in fish: Chilodonella hexasticha Kiernik, 1909, mainly found in tropical fishes and C. piscicola (Zacharias, 1894) Jankowski, 1980 (syn. C. cyprini Moroff, 1902) mainly parasitizing fishes from subtropical and temperate waters. In Brazil, Pádua et al. (2013a) have reported for the first time C. hexasticha causing outbreak mortality in Nile tilapia (Oreochromis niloticus), pacu (Piaractus mesopotamicus), and tuvira (Gymnotus aff. inaequilabiatus).

\section{Life cycle}

Chilodonellids show monoxenic life cycle with transversal division on the host (Figure $2 \mathrm{~d}$ ), besides sexual reproduction by conjugation (PYNE et al., 1974; PÁDUA et al., 2013a). Some researchers suggest that chilodonellids have one life stage capable of forming resistant cysts for parasite maintenance, but this strategy is not yet fully understood.

\section{Transmission}

The transmission of chilodonellosis occurs especially by direct contact among infested and healthy fish. The parasite disseminates in fish farming via routine utensils and water in fish transporting, which can be considered as the most important dispersion factors.


Figure 2. Chilodonella hexasticha observed in fresh-mounted slide from the gills of Nile tilapia Oreochromis niloticus (a), with detail of ciliary kineties in silver nitrate impregnation (b), nuclear apparatus and great amount of bacteria when stained by Giemsa (c), transversal fission of the parasite after silver nitrate impregnation (d). Bar: $10 \mu \mathrm{m}(\mathrm{b}, \mathrm{d})$. 


\section{Diagnosis}

Diagnosis can be made from microscopic examination of freshmounted scraps of the skin, fins and gills of suspected fish. In freshmounted slides the rapid movement of the parasite, generally to a single direction can be easily detected. Silver nitrate impregnation technique allied to Giemsa or haematoxylin staining procedures are fundamental to observe the main taxonomic characters for specific identification (PÁDUA et al., 2013a). The numbers of ciliary kineties constitute the most important taxonomic character that distinguishes $C$. hexasticha from $C$. piscicola. In this way, C. piscicola has more numerous and less spaced ciliary kineties (KAZUBSKI \& MIGALA, 1974).

Histological techniques also allow the researcher to find out the definitive diagnosis. However, not all details can be observed in infested tissue from histological sections, allowing only its determination at the generic level.

\section{Pathogenesis and clinical signs}

Infestations by Chilodonella cause severe lesions when compared to other ciliates with similar lifestyle, as for example trichodinids. Pathological changes caused by Chilodonella are related to its abrasive action on the host epithelium, being the gill filaments the most sensitive organ to the parasite attack. In acute cases, an increase in the mucus production with consequent congestion of the gills maybe found. Consequently in severely infested fish, epithelial proliferation, necrosis and desquamation culminating in blood capillary rupture and mononuclear inflammatory cell infiltrate can be found (PÁDUA et al., 2013a). Since host health and defense system are strongly affected, the disease is frequently accompanied by bacterial opportunistic secondary infections (Figure 1c) that provoke systemic infection and host death.

Clinical manifestation comprises non-specific signs such as respiratory difficulty, loss of equilibrium and appetite. Apart from these alterations, whitish lesions on the gills, scaleness, darkened skin, skin and fins ulcers, and haemorrhagic areas are common in mixed infection with bacteria.

Epistylis Ehrenberg, 1830

Representatives of Epistylis are colonial ciliates with bell-shaped body, provided by a long peduncle (not contractile) in which, in the apex, is located the zooid cell with a nucleus, contractile vacuoles and cilia (LOM \& DYKOVÁ, 1992). Similar to Apiosoma, this sessile peritrichid uses fish as a substrate for attachment (epibiosis) and feeds on suspended particles in the water (PÁDUA et al., 2012a). When present in a population under high stocking densities associated with bacteria that colonizes its peduncle, this ciliate might cause host damage and then be named as parasite. In Brazil, epistyliasis has been characterized as an emergent disease with greater impact in farmed catfish (ISHIKAWA et al., 2012; PÁDUA et al., 2012a,b, 2013b).

\section{Life cycle}

These ciliates rely on binary fission of the zooids (Figure 3b) for asexual propagation, but they may reproduce by conjugation on its sexual reproduction (ISHIKAWA et al., 2012). Similar to Apiosoma, it occurs as non-sessile telotrochs in the water column (ISHIKAWA et al., 2012).
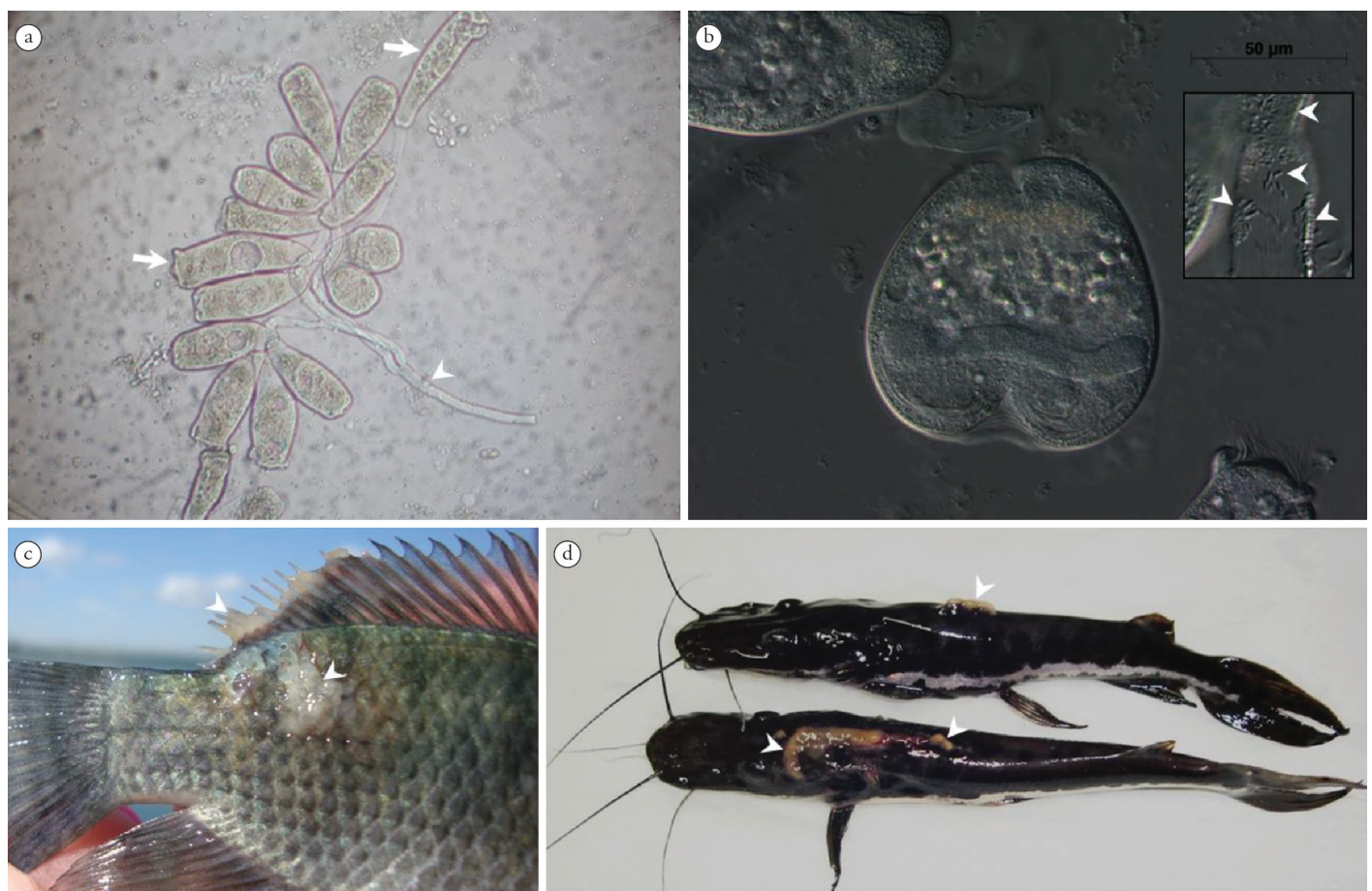

Figure 3. Epistylis sp. (a) in fresh-mounted slide under light microscope. Zooid in binary fission (b) and detail of bacteria (arrow heads) attached on the peduncle of the ciliate. Nile tilapia Oreochromis niloticus (c) with fin erosion and loss of scale (arrowheads) associated with Epistylis colonization, and hybrid surubim Pseudoplatystoma sp. (d) showing total erosion of dorsal fin and colonies of Epistylis sp. on the dorsal fin and head (arrow heads). 


\section{Transmission}

Epistyliasis is transmitted from infective telotrochs searching for new hosts for attachment to develop new colonies. In addition, Pádua et al. (2013b) suggested that zooplanctonic microcrustaceans may act as vectors or reservoir hosts for Epistylis in farming conditions. In fact, it is common to find these ciliates fixed on the body surface of those organisms increasing thus disease dissemination (VISSE, 2007). Besides, it is a routine practice for fish farming to add manure to the ponds in order to improve the primary productivity of the water resulting in increased phytoplankton and zooplancton production for fish feeding. Nevertheless, as a result of the addition of nutrients into the water, the sanitary risk of an increase in the number of disease-vectors protozoans is imminent.

\section{Diagnosis}

Macroscopical observation of epistyliasis from whitish to yellowish colonies on the fish surface, fins, operculum, head and mouth should be accompanied by fresh-mounted slides observed in microscope (Figure 3a). This is especially true because observation of parasite colonies at first view (naked eye) can lead to misleading or confusing diagnosis since it can be easily confused with fungal infection. From microscopic observation, contraction movements of the zooids afford the definitive diagnosis. As complementary material, the histopathological analysis provides a more comprehensive view of the disease and its effect on tissues but do not preserve the important characteristics found in fresh-mounted material. In early infestation it is not possible to detect the colonies by the naked eye (PÁDUA et al., 2013b), being necessary to examine scraps from skin, fins and gills.

The identification at specific level from in vivo analysis must be complemented in samples impregnated with silver proteinate (protargol). Length and width of zooid, cell and colony shape, peristomial lips diameter, arrangement of buccal ciliary, nucleus shape and legth and width of peduncle are important characteristics to be measured (LI et al., 2012).

\section{Differential diagnosis}

To confirm Epistylis on fish, microscopical analysis is fundamental, once the fungus Saprolegnia sp. can also develop colonies visible to the naked eye. It can be differentiated from the other sessile peritrichids, Apiosoma and Ambiphrya, by the formation of branched colonies. On the other hand, other ciliates not commonly found to be parasitizing fish such as Zoothamnium and Carchesium also develop branched colonies similar to Epistylis. Nevertheless, they differ from the latter in their peduncle contraction movement.

\section{Pathogenesis and clinical signs}

Its pathology is strongly associated with the presence of bacteria on the peduncle (Figure 3b, arrow heads). As they do not invade directly the host cells in the attachment process, neither pathological alterations in infested tissue nor substances are released on the host surface (HAZEN et al., 1978). Moreover, these authors confirmed the involvement of Aeromonas hydrophila as the bacterium responsible in colonizing the parasite and secreting lytic enzimes that degrade the adjacent tissue. In this case, haemorrhagic alterations associated with peritrichid colonies in channel catfish can determine the red-sore disease. The colonization of parasite depends on the fish species and developmental stage of fish as well as the production system conditions.

In highly infested fish by Epistylis sp. it can be seen fin erosion and skin ulcers related to bacterial enzymes activity (Figure 3c,d). On histological sections, degeneration and epithelial necrosis adjacent to the colonies, intense desquamation, as well as increased mucus production and inflammatory infiltrate are also related (PÁDUA et al., 2012a). The fish death occurs generally after secondary invasion by opportunistic bacteria thus causing systemic infection.

Ichthyophthirius multifiliis Fouquet, 1876

The causative agent of ichthyophthiriasis or white spot disease is one of the most important fish parasites of worldwide distribution compromising skin, fins, gills and eyes of farmed fish. This parasite is not host specific and any freshwater fish can potentially transmit the parasite (EIRAS, 2013a). Similar to that found for channel catfish (Ictalurus punctatus) in the United States (XU \&KLESIUS, 2004), in Brazil it is considered an important parasitic disease in farmed hybrid surubim catfish (Pseudoplatystoma sp.) (ISHIKAWA et al., 2012), including the Central-North region of Brazil where water temperature variations are less frequent.

During a parasitological survey of ornamental fishes from North Brazil, Tavares-Dias et al. (2009) identified I. multifiliis in the gills of Paracheirodon axelrodi, Hyphessobrycon copelandi and Dianema urostriatum. Several fish species are susceptible to I. multifiliis including the silver catfish jundiá (Rhamdia quelen) (MARTINS et al., 2013) and the amazonian hybrid pintado (Pseudoplatystoma sp. x Leiarius marmoratus) are susceptible to I. multifiliis.

\section{Life cycle}

The life cycle of I. multifiliis is monoxenic and involves only a fish to be completed. Similar to Amyloodinium and Piscinoodinium, its life cycle has three stages as follows:

I. Theront: infective and mobile form measuring 30 to $50 \mu \mathrm{m}$; it needs to find a host otherwise it will die. Theronts are provided by a structure named perforatorium used in fish cell invasion.

II. Trophont: adult mobile stage found in fish epithelium, can reach 800 to $1,000 \mu \mathrm{m}$ in diameter.

III. Tomont: free form of the parasite provided by a cyst for protection. Attaches to plants and substrate to divide asexually and originate 500 to 1000 daughter cells named tomites that will differentiate in infective theronts and so search for a new host.

\section{Transmission}

Its transmission occurs by co-habitation (XU et al., 2007) with infested fish or directly from the theronts. Fishery utensils used in fish farms and water transport are potential vectors of ichthyophthiriasis. The release of theronts into the water is strongly associated with temperature. At water temperatures above 
$24^{\circ} \mathrm{C}$, the life cycle is favored and completed rapidly. Differently, temperatures below $10^{\circ} \mathrm{C}$ or above $28^{\circ} \mathrm{C}$ can inhibit the parasite life cycle (ISHIKAWA et al., 2012). An exception, however, must be commented when it was observed mortalities of up to $50 \%$ in fingerlings of tambaqui Colossoma macropomum infected with I. multifiliis at Central-North and North regions of Brazil, when water temperatures ranged from 29.5 to $31.5^{\circ} \mathrm{C}$ (PÁDUA, S.B. personal communication). In this way, studies on different strains of $I$. multifiliis to verify its susceptibility under uncommon conditions must be encouraged.

\section{Diagnosis}

Ichthyophthiriasis diagnosis is made based on macroscopical observation of trophonts within the host's skin and microscopical analysis of fresh-mounted material (skin, fins and gills scraps) between a slide and a coverslip (Figure 4a). Under an optical microscope, the observation of the mobile pear-shaped theronts and mature trophonts uniformly covered by a layer of external cilia and with a horse-shoe shaped nucleus confirms the diagnosis (Figure 4b). Histopathological analysis can also reveals the parasitosis (Figure 4c,d).

\section{Differential diagnosis}

Because of its similarity with the dinoflagellate Piscinoodinium pillulare, definitive diagnosis ought to be careful. This dinoflagellate shows similar color and shape to I. multifiliis, but does not swim and has no cilia around the body. Moreover, P. pillulare has rounded nucleus instead of the horse-shoe shaped nucleus in I. multifiliis.

\section{Pathogenesis and clinical signs}

Pathological alterations associated with ichthyophthiriasis are related to theront invasion on the epithelium layers with posterior histophagia stage of trophont. This process provokes inflammatory reaction of the host with intense epithelial proliferation by goblet cells, and in severe cases it can be observed fusion of secondary lamellae, degeneration and epithelial cell necrosis forming several ulcers on the epithelium after the releasing of mature trophonts (PÁDUA et al., 2014).

The main clinical sign is the presence of white spots on the fish surface including skin, fins, eyes, buccal cavity and gills. It is common to observe fish with respiratory difficulty, flashing behavior in ponds and aquaria, and in cage-reared fish flashing on the sieve cages, leading to muddy water in earth ponds (MARTINS et al., 2000; ISHIKAWA et al., 2012).

Trichodinidae Claus, 1874

Trichodinids are mobile ciliates characterized by the presence of a body covered by a slender membrane surrounded by an adoral ciliary spiral, a horse-shoe shaped macronucleus and an adhesive disc provided with a denticulate ring in which the denticles are found (Figure 5c) (BASSON \& VAN AS, 2006). In Brazil, the genera Trichodina, Paratrichodina, Tripartiella and Trichodinella have been found parasitizing aquatic animals (PÁDUA et al., 2011a), including zooplanctonic microcrustacean (SILVA et al., 2009), gastropod mollusc (PINTO et al., 2006), bivalve mollusc from mangrove


Figure 4. Hybrid surubim Pseudoplatystoma sp. presenting white spots on the skin and fins (a). Ichthyophthirius multifiliis observed in freshmounted slide from the skin: mature trophont and its horse-shoe shaped macronucleus (b - arrowhead) and several imature trophonts in developmental stages ( $b$ - continued arrow). Histological section of the gill lamellae (c), with inflammatory infiltrate (c - asterisk), and the parasite inserted in the skin of infected fish ( $\mathrm{d}$ - arrow head). Proliferation of mucous cells next to the parasite attachment (d - dotted arrows). Bar: $150 \mu \mathrm{m}$ (c) and $100 \mu \mathrm{m}$ (d). Figure 4 a was obtained from Pádua et al. (2012b) and Figure 4 d from Pádua et al. (2014). 
(SABRY et al., 2013), ornamental fishes (MARTINS et al., 2012), wild fishes (BITTENCOURT et al., 2014), as well as farmed fish (VALLADÃO et al., 2013) and amphibians (FERNANDES et al., 2011). Until 2006 trichodinids from farmed fishes in Brazil were recognized only at their generic level. From that year on, several studies have been performed in order to identify trichodinids at specific level (GHIRALDELLI et al., 2006; PINTO et al., 2009; JERÔNIMO et al., 2011; MARTINS et al., 2010a; MARTINS et al., 2012; MIRANDA et al., 2012; PÁDUA et al., 2012c).

Trichodinids can be found parasitizing both freshwater and marine fishes on the body surface, buccal cavity and gills. Nevertheless, relatively few of them have become endoparasites in the intestine, kidney and urinary bladder of their hosts (LOM \& DYKOVÁ, 1992). Proliferation of the group in the environment seems to be associated with bad water quality, total number of bacteria and ecological aspects of the fish species. In this way, the use of trichodinids as an indicator for eutrophication in brackish-water environments was suggested (PALM \& DOBBERSTEIN, 1999).

Their reproduction in fish farms has been related to high stocking density, high organic matter contents and increased water temperature (BASSON \& VAN AS, 2006; MARTINS et al., 2010b). Differently, some trichodinid species were found to be suppressed with increased water temperature (YEMMEN et al., 2011).

\section{Life cycle}

Trichodinids have monoxenic life cycle and reproduce mainly by binary fission (conjugation is also possible) on the host (Figure $5 \mathrm{~d}$ ). In a short period of time they can reproduce rapidly and reach 100\% prevalence and up to 299,100 parasites per host as observed by Martins et al. (2010b).

\section{Transmission}

Trichodinids can be horizontally transmitted by direct contact or by contaminated water in which the parasite searches for new hosts. Contaminated fish farming utensils are also another important source of trichodinids transmission.

\section{Diagnosis}

Trichodinid diagnosis can be made from scraps of skin, fins and gills of diseased fish observed under a stereomicroscope by an expert researcher or under a microscope (Figure 5a,b). In fresh-mounted material between a slide and a coverslip the parasites move rapidly in circle. The most important techniques for specific diagnosis are silver nitrate impregnation (Figure 5c) and staining by Giemsa or haematoxylin (LOM, 1958; VAN AS \& BASSON, 1989).
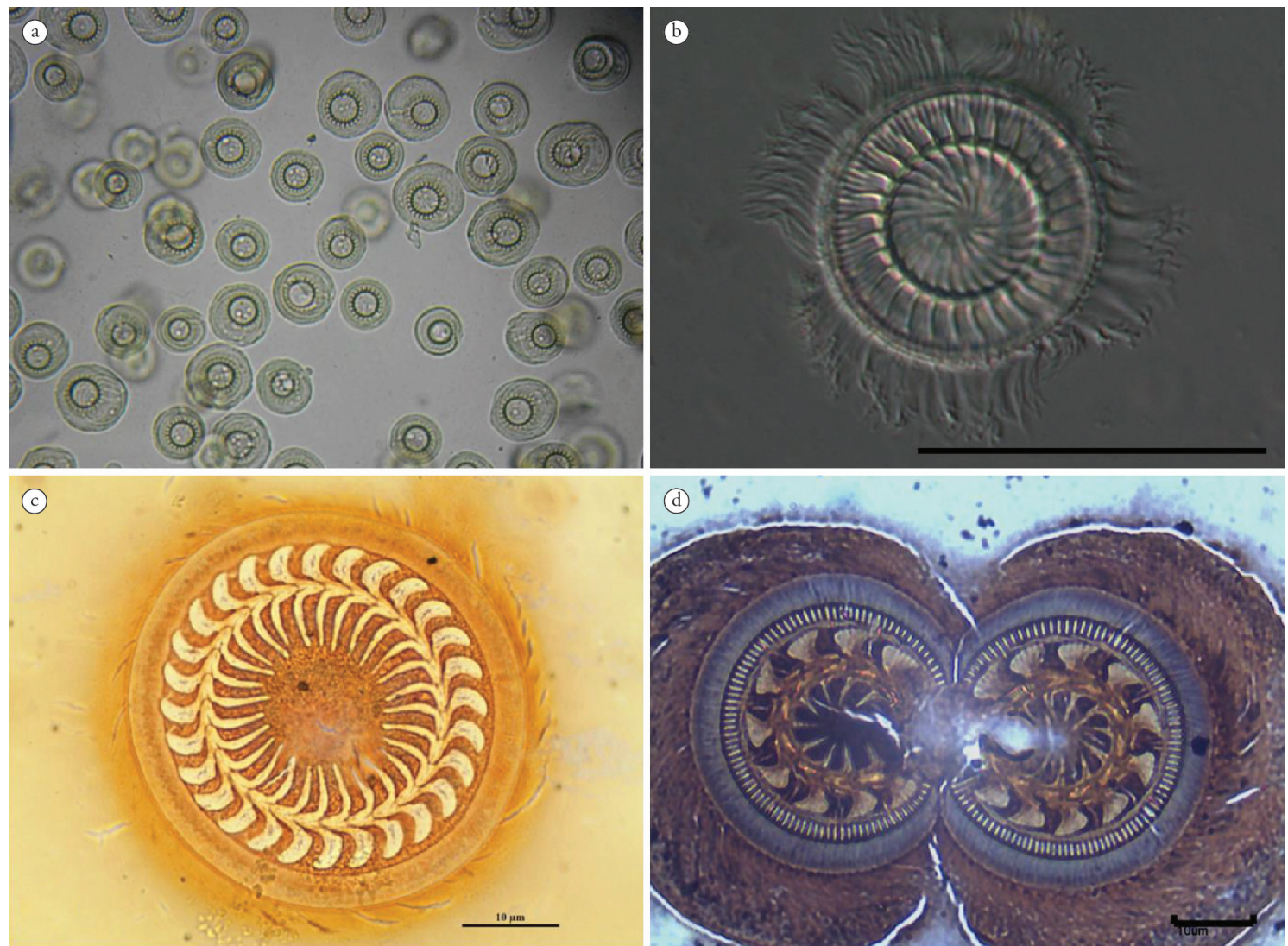

Figure 5. Trichodinids in fresh-mounted smear from the skin (a), Trichodina centrostrigeata in differential interference contrast microscope (b), adhesive disc of Trichodina magna in silver nitrate impregnation (c) and an adhesive disc of a trichodinid during binary fission in silver nitrate impregnation (d). Bar: $50 \mu \mathrm{m}$ (b) and $10 \mu \mathrm{m}$ (c,d). 
Histological sections can also allow identifying the parasites only at the family level, because the shape of the denticles varies within and between the genera.

\section{Pathogenesis and clinical signs}

According to Basson and Van As (2006), in a "firmly attached Trichodina, the rim of the border membrane "bites" into the surfaces of the fish's epithelial cells, and the surface it encircles is forcibly vaulted as by a sucker"; these activities (attachment and rotating movements) may cause serious irritation and damage to the epithelial or epidermal cells of fish.

The disease may occur in acute form mainly in larvae and fingerlings causing ulcers, subepithelial oedema, displacement of the secondary lamellae in the gill filaments, hyperplasia and mononuclear inflammatory infiltration (VALLADÃO et al., 2014). On the other hand, in chronic infestations trichodinids may induce an increase in the mucus cells of the epithelium and gill filaments, discrete hyperplasia with partial or total fusion of the secondary lamellae, inflammatory infiltrate and gill necrosis (VALLADÃO et al., 2013). The micro-lesions caused by the presence of these parasites are next colonized by bacteria (VALLADÁO et al., 2014), which, in turn, are responsible for opportunistic infections and accelerate the progression of the disease thus causing outbreaks of mortality.

Clinical signs are not specific and diseased fish may present darkness of the skin, whitish areas in the gills, hypoxia and flashing on the ponds or aquaria surface (PÁDUA et al., 2011a). Lethargy and erratic swimming on the body surface are frequently found in diseased fish larvae (VALLADÃO et al., 2013).

\section{Flagellata}

Flagellate protozoans are mainly characterized by the presence of one or more flagella for movement. The majority of them are ectoparasites while others can be found parasitizing internal organs (EIRAS, 1994). They reproduce by longitudinal binary fission as for kinetoplastids or present a three-phased life cycle such as dinoflagellates. Amyloodinium ocellatum, Piscinoodinium pillulare, Trypanosoma, Cryptobia and Ichthyobodo are the main representatives.

Amyloodinium ocellatum Brown et Hovasse, 1946

Amyloodinium comprises dinoflagellates of varied shape depending on the life stage. The causative agent of velvet disease A. ocellatum is ubiquitous, affects marine farmed fish and may provoke important outbreak mortalities and economical losses in aquaculture systems (LEVY et al., 2007; PEREIRA et al., 2011; MOREIRA et al., 2013). The trophont stage is pear or roundedshaped, has golden to brownish color, presents chloroplasts and is capable of feeding when adhered on the fish surface or gills by its rhizocysts. The tomont is the reproductive form (it encysts on the substrate) and the dinospore corresponds to the infective free-swimming stage with a longitudinal and transverse flagellum (NOGA, 1987; GUERRA-SANTOS et al., 2012; WOO \& ARDELLI, 2014).

\section{Life cycle}

The life cycle has no intermediate hosts and presents the following three stages: dinospore, the infective form; trophont, that develops on the host; and tomont, the reproductive stage with consecutive divisions developed on the ponds or aquaria substrates (Figure 6). Reproduction by binary fission occurs when tomonts divide repeatedly producing the free-swimming infective dinospores (FRANCIS-FLOYD \& FLOYD, 2011; WOO \& ARDELLI, 2014).

\section{Transmission}

Obligatory parasite of monoxenic life cycle, Amyloodinium has low host specificity parasitizing mainly the gills followed by skin of farmed and wild marine and estuary fishes (REED \& FRANCIS-FLOYD, 1994; ABREU et al., 2005; WOO, 2007). It can be transmitted by direct contact with infective dinospores present in the water. In open aquaculture systems, such as cage farming, the parasite can be easily transmitted to wild fish. In this way, Roberts-Thomson et al. (2006) related tomonts of $A$. ocellatum transported by dynamic airflow system until 2 meters from the source of infection. The capacity of transport or dissemination of tomonts was proved by those authors and constitute one more possibility of infection in indoor systems.

\section{Diagnosis}

Diagnosis of $A$. ocellatum is made from scrapings of body surface and gills between a glass slide and a coverslip to be observed in stereomicroscope or light microscope (MONTGOMERYBROCK et al., 2001; ABREU et al., 2005; GUERRA-SANTOS et al., 2012). In addition, microscopic examination of histological

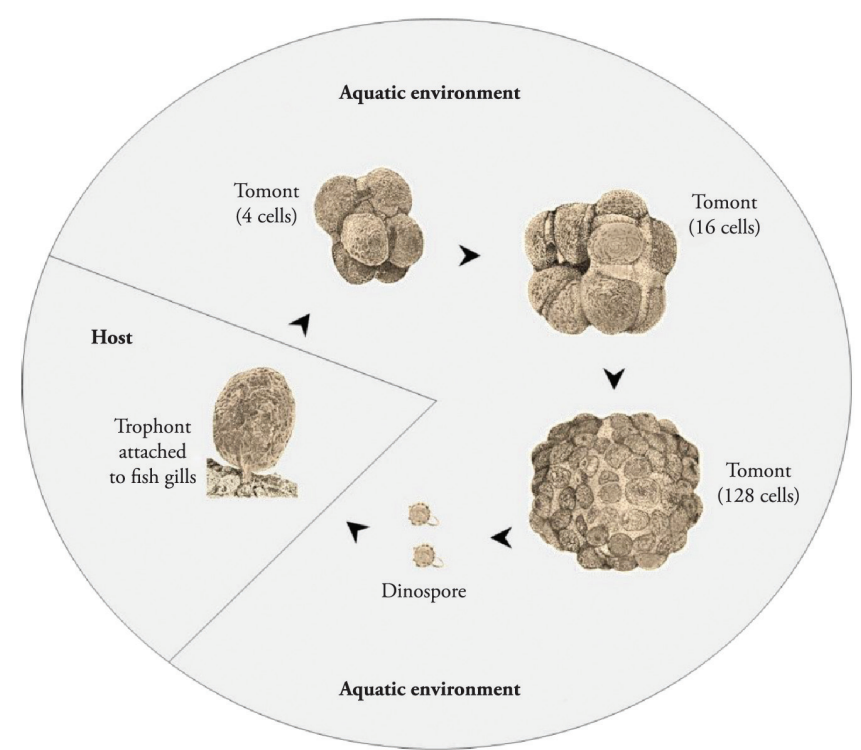

Figure 6. Life-cycle of Amyloodinium ocellatum. Modified from Pereira et al. (2011). 
sections of parasitized tissue also reveals the presence of the parasite (GUERRA-SANTOS et al., 2012), while the serological exam with the presence of specific antibodies is yet little explored (CECCHINI et al., 2001). Its fixation is made directly in the slides with 5\% formalin solution or in a flask with $10 \%$ buffered formaline solution for histopathology. The most applied staining techniques are May-grunwald and Giemsa or haematoxylin and eosin (GUERRA-SANTOS, 2011), as well as iodine to evidence the amyloid granules.

In dinospores, the presence of longitudinal and transverse flagella, length and width of cellular body, distribution pattern of epitheca and hypotheca plates and observation of a peduncle, rhizocysts, pores and nodules are the main characteristics for parasite identification (LANDSBERG et al., 1994), as well as genetic information and trophont measurements (ABREU et al., 2005).

\section{Pathogenesis and clinical signs}

Tissue alteration on the host is a result of the mechanical action of trophonts during the attachment process by the ryzoids on the epithelial cells. Among the acute pathological changes an increase in mucus production and gill congestion is common (GUERRA-SANTOS et al., 2012), frequently leading to vacuolar degeneration, epithelial rupture, hyperplasia and fusion of the secondary lamellae and necrosis in severely affected fish (CRUZLACIERDA et al., 2004; SARAIVA et al., 2011).

Anorexia, erratic swimming, lethargy, "flashing" onto the substrates, skin depigmentation, emaciation and branchial hyperventilation are the main clinical signs (ABREU et al., 2005; FRANCIS-FLOYD \& FLOYD, 2011; GUERRA-SANTOS et al., 2012).

\section{Piscinoodinium pillulare Lom, 1981}

Causative agent of piscinoodiniasis or velvet disease has similar morphological and developmental characteristics of A. ocellatum but is considered an important parasite in freshwater fish (NOGA \& LEVY, 2006). With worldwide distribution, this parasite is not host-specific (MARTINS et al., 2001) and is responsible for important sanitary problems in Brazil in native farmed fishes such as tambaqui (Colossoma macropomum), pacu (Piaractus mesopotamicus), pirapitinga (Piaractus brachypomus) besides their hybrids, piauçu (Leporinus macrocephalus) and curimbatá (Prochilodus lineatus), in hatchery of Amazonian pintado (SILVA, W.C. personal communication), in exotic channel catfish (Ictalurus punctatus) and less frequently in Nile tilapia (Oreochromis niloticus). This dinoflagellate was also reported in five ornamental freshwater fishes from an exporter's holding facility in the Amazonas State (TAVARES-DIAS et al., 2009). Under a microscope, it can be observed three forms of the dinoflagellate from the scraps of fish: pear-shaped, banana-shaped and the mature rounded parasite of brownish color (MARTINS et al., 2001; FOIN, 2005), although in high infestations different developmental stages can be found. Special care must be taken on the mature trophonts that could be confused with I. multifiliis by an inexperienced person.

\section{Life cycle}

Its life cycle is similar to A. ocellatum (three-phased cycle), with trophont, tomont and dinospore on the host or aquatic environment. Imobile trophonts adhere to hosts by their rhizocysts (KLINGER \& FRANCIS-FLOYD, 1998; FOIN, 2005). Tomonts on the substrate undergo sucessive divisions in order to originate free-swimming dinospores provided with flagella.

\section{Transmission}

Piscinoodiniasis can be transmitted by contact with infested fish and dinospores from contaminated water (FOIN, 2005) and also by fish farming utensils with no disinfection after using them. The transport of live fish among fish farms represents an efficient way of transmission of infectious-parasitic diseases once the water can load infective or resistant stages of parasites, bacteria and viruses of sanitary importance.

\section{Diagnosis}

Traditional evaluation by scraps from the body surface and gills observed in stereomicroscope or microscope is used to diagnose piscinoodiniasis in fish. The detection of trophonts stage allows the definitive diagnosis in posterior slides fixed in methylic alcohol for $10 \mathrm{~min}$ and stained with diluted Giemsa (one drop per $1 \mathrm{~mL}$ of distilled water for 120 to $180 \mathrm{~min}$ ) (Figure 7) or iodine staining to view the amyloid granules (MARTINS et al., 2001). Routine histopathological analysis may also provide definitive diagnosis by viewing the trophonts attached on the gill filaments. As low parasitic infestations do not cause clinical signs and disease in fish, prophylactic measures must adopted.

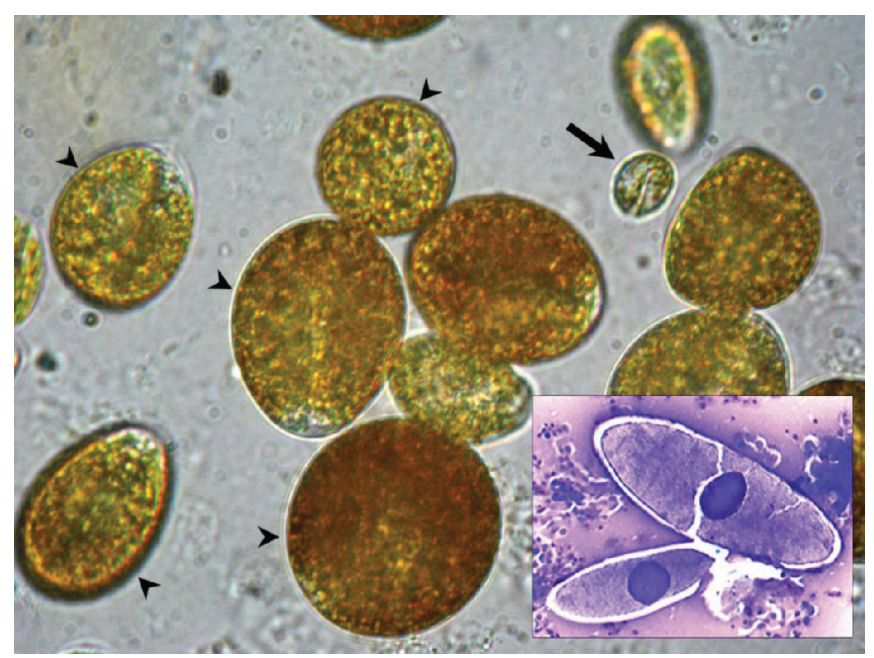

Figure 7. Piscinoodinium pillulare from gill scraps of tambaqui Colossoma macropomum. Pear-shaped trophonts, rounded (arrowheads) and one dinospore (arrow). In detail, two parasites stained in Giemsa exhibiting oval to rounded nucleus with the absence of micronucleus. 


\section{Pathogenesis and clinical signs}

Pathological alterations are associated with the mechanical action of the parasite after attachment to the host. In this stage trophonts insert their rhizocysts from the fixing disc and invade the cytoplasm of epithelial cells of the host (LOM \& SCHUBERT, 1983).

In low parasitic levels is common to observe an increase in the mucus production and gill congestion. On the other hand, in severe infections where the disease leads to a chronical form it has been observed proliferative alterations, including fusion of the secondary lamellae, mucus cell proliferation, inflammatory cell infiltration associated with degeneration and necrosis of the epithelial cells, subepithelial oedema, haemorhages and ulcers (MARTINS et al., 2001). Recently, a case of mixed parasitism by P. pillulare and a myxozoan parasite in farmed fish was reported by Sant'Ana et al. (2012), when $90 \%$ of diseased fish died in 15 days.

Proliferative disturbs in the gills associated with the interlamellar presence of parasites are responsible for hypoxia, loss of equilibrium and erratic movements (SANT'ANA et al., 2012). Consequently, fish search for for more oxygen on the water surface or water inlet in ponds. Heavily infested fish present "flashing" on the substrate as a response of parasite's irritant action. Macroscopical observation of gills heavily infested by $P$. pillulare may reveal brownish coloration (Figure 8a,b). Trophonts of $P$. pillulare attach mainly on the primary lamellae filling all the interlamellar space between the secondary lamellae (Figure 8c), where the rhizocysts can be found attached to the host epithelial cells (Figure 8d).

Trypanosoma Gruby, 1843

This haemoflagellate parasite is ubiquitous throughout freshwater and marine environments and may cause problems in aquaculture. Members of Trypanosoma present a slender body, elongated, cylinder-shaped with more or less thin extremities, free flagellum, undulating membrane besides the nucleus and kinetoplast (Figure 9a) and volutin granules disposed generally in the middle of the body (HUSSEIN et al., 2010).

\section{Life cycle}

These protozoans have a heteroxenic life cycle involving an annelid Hirudinea as an intermediate host and vertebrates as definitive hosts. However, little is known about the distinct stages of their life cycle infecting South American fishes and, additionally, they are rarely found in farmed fish. During the infectious process on the host, asexual reproduction by cellular division was described in infected knifefish Gymnotus aff. inaequilabiatus (PÁDUA et al., 2011b). Tripomastigote, epimastigote, amastigote and several dividing flagellate forms were observed in the stomach of leech


Figure 8. Pathological changes in fish with piscinoodiniasis. Brownish gill of tambaqui Colossoma macropomum (a), hundreds of parasites adhered in gill filaments observed in stereomicroscope (b), as well as from histological section (c), rhizocysts penetrating host's skin (d - arrow). Bar: $100 \mu \mathrm{m}(\mathrm{c})$ and $25 \mu \mathrm{m}(\mathrm{d})$. 

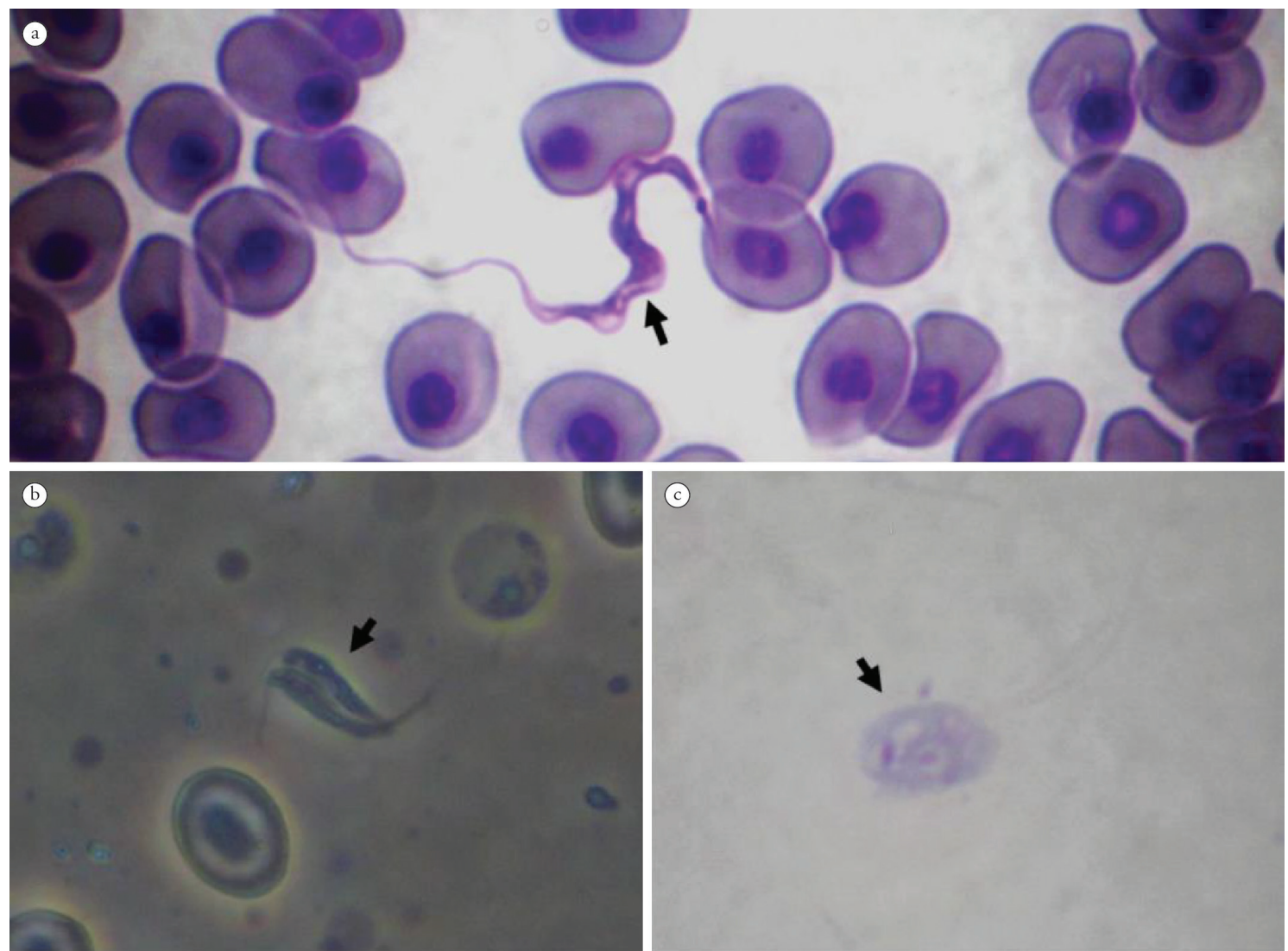

Figure 9. Trypanosoma sp. (a) observed from blood extension of tuvira Gymnotus aff. inaequilabiatus; Cryptobia sp. (b) from gill scraps of hybrid tambacu (C. macropomum x P. mesopotamicus) observed in a phase-contrast microscope and Ichthyobodo sp. (c) from skin of Nile tilapia Oreochromis niloticus previously stained with Giemsa. Figure 9 a was obtained from Pádua et al. (2011b).

Batracobdella gemmata, vector of trypanosomiasis to the loricariid catfish Hypostomus punctatus (D'AGOSTO \& SERRA-FREIRE, 1993).

\section{Transmission}

Transmission occurs during the leech parasitism on fishes (BRUNO et al., 2006) and in the case of loricariids, they are found attached to the regions of the body not covered by plates or on the gill filaments inoculating the infective form (D'AGOSTO \& SERRA-FREIRE, 1993).

\section{Diagnosis}

Blood smears stained with a combination of May GrünwaldGiemsa or May Grünwald-Giemsa-Wright or only Giemsa are simple techniques for morphological characterization of the haemoflagellates. Nevertheless, this is a low-sensitive method and because of that, it is recommended to prepare fresh-mounted slides with a drop of blood between a glass and a coverslip as well as centrifuge the blood in a microhaematocrit tube for parasite concentration in order to provide high-sensitive method for diagnosis (WOO, 1969).

Histological sections of the liver, spleen and kidney stained with Ehrlich haematoxylin and eosin can improve the diagnosis
(HUSSEIN et al., 2010). Parasite identification at species level should be performed by analysis of morphological and morphometric characteristics (total length, width, nucleus length and width, distance from the nucleus centre to the posterior and anterior extremities, flagellum length and number of undulating membrane), besides application of molecular phylogenetic methods (MASLOV et al., 2001; HUSSEIN et al., 2010; FERREIRA \& AVENANT-OLDEWAGE, 2013). Molecular tools for DNA detection are poorly explored in diagnosis of tryponosomiasis in fish from Brazil despite their recognized importance.

\section{Pathogenesis and clinical signs}

In case of cultured fish condition high levels of parasitism could be responsible for lethargy, gill paleness, splenomegaly, nephromegaly and altered color of the liver.

Cryptobia Leidy, 1846

These biflagellates have a triangulate to elongated body shape, a kinetoplast and a nucleus at the anterior end. Two flagella arise at the anterior end; the anterior flagellum is free while the recurrent one is attached to the body and extends beyond it as a free flagellum responsable for the movement (Figure 9b) (KUPERMAN et al., 2002; BRUNO et al., 2006). It can be found parasitizing either the gills or skin of marine and freshwater fishes around the world and the majority of them are ectocommensals. However, some 
species are pathogenic for young fish (KUPERMAN et al., 2002; RANZANI-PAIVA et al., 2005).

Cryptobia branchialis Nie (Chen, 1956) has been registered in different continents (KUPERMAN et al., 2002). In Brazil, several occurrences of Cryptobia sp. exist (EIRAS et al., 2012), but so far little is known about the parasite species involved. High infestations by this flagellate are frequently diagnosed on pacu, tambaqui, pirapitinga and their hybrids, as well as Nile tilapia, the hybrid surubim (Pseudoplatystoma spp.) and hybrid Amazonian pintado.

\section{Life cycle}

Cryptobia presents monoxenic life cycle, with longitudinal fission occuring on the host to posterior dettachment from the gills of the host to be free in water column (KUPERMAN et al., 2002).

\section{Transmission}

It presents horizontal transmission either by direct contact (host to host) or contaminated water with free-swimming infective forms. Fishery utensils as well as the water used in fish transport might be the source of parasitism in aquaculture facilities.

\section{Diagnosis}

Cryptobiosis can be diagnosed by observation of fresh-mounted smears of skin and gills under microscope. Later, infected smears can be stained with, for example, silver albumose (protargol) impregnation in order to provide a correct diagnosis. For fixation prior to impregnation, Hollande's fluid can be used (KOZLOFF, 2004). Observation of flagella, length and body width, nucleus diameter, cell shape and the aciculum (a bunch of microtubules to reinforce the parasite pharynx) are some of the most important diagnostic features for Cryptobia. Differently, the observation of flagella, disposition and contraction movement are fundamental information to the correct diagnosis. After that, the smears containing the parasites must be stained for posterior analysis under a light microscope (for example, protargol impregnation as recommended by Kozloff (2004)), in order to evidence the flagelli, nucleus, cell chape and the presence of aciculum. Bruno et al. (2006) used the techniques of Feulgen or Giemsa staining for observation of the kinetoplast.

A combination of fixative solution containing methylic alcohol for $10 \mathrm{~min}$ and later staining with diluted Giemsa (one drop per $1 \mathrm{~mL}$ of distilled water, for 120 to $180 \mathrm{~min}$ ) affords a detailed observation of parasite morphology, although flagella are poorly evidenced. The length and body width, flagelli length, nucleus diameter and position as well as the length and position of kinetoplast, and the cell shape are used for identification at specific level (PUTZ, 1972; KOZLOFF, 2004).

\section{Differential diagnosis}

The diagnosis of Cryptobia sp. in the gills must be made carefully due to its similarity with Ichthyobodo spp. (both have two flagella). Nevertheless, Ichthyobodo is mainly found on the skin. In order to differentiate both parasites, fresh-mounted microscope slides with special aware of flagella's arrangement are useful. Cryptobia sp. presents flagella with rapid movements while in Ichthyobodo the flagella move in circles.

\section{Pathogenesis and clinical signs}

Its pathogenicity is controverted and the findings of Kuperman et al. (2002) suggest that the parasite neither invades the host cells during the attachment process nor cause pathological alterations. However, observations from young tilapia highly infested by the parasite showed a direct relation with an increase in the gill mucus production, gill filaments oedema and reduced respiratory lamellae (KUPERMAN et al., 2002).

\section{Ichthyobodo Pinto, 1928}

Causative agent of ichthyobodiasis, these obligatory parasites are small biflagellated kinetoplastids found in skin, fins and gills of wild and farmed marine and freshwater fishes from temperate and tropical waters (ROBERTSON, 1985; LOM \& DYKOVÁ, 1992; TODAL et al., 2004). Widely distributed, Ichthyobodo necator (Henneguy, 1883) was registered in different fish species from Brazil (EIRAS et al., 2012). Similar to Cryptobia, it is pearshaped (Figure 9c) and when fixed on the host it shows circling or zigzag movements (LOM \& DYKOVÁ, 1992).

\section{Life cycle}

Ichthyobodo presents monoxenic life cycle, asexual reproduction in which occurs the longitudinal fission of the parasite cell (ROBERTSON, 1985). Cells containing two pairs of flagella can be found moments before binary fission (LOM \& DYKOVÁ, 1992).

\section{Transmission}

The parasitosis is horizontally transmitted by direct contact among diseased and healthy fish. Free-swimming infective parasites are responsible for disease dissemination as well as contaminated fishery utensils.

\section{Diagnosis}

Fresh-mounted smears of skin and gills viewed under microscope constitute the most employed technique for routine diagnosis. Cryptobia is more or less pyriform and has two unequal flagella extending posterior-laterally, while Ichthyobodo is more elongateshaped and has two flagella, one posterior and one recurrent which is attached to the body forming the posterior free flagellum.

Smears previously fixed in methylic alcohol and stained with haematoxylin, Feulgen or Giemsa can be used for microscopical analysis (LOM \& DYKOVÁ, 1992; TODAL et al., 2004; ISAKSEN, 2013). The distribution pattern and kinetoplast morphology are useful information for specific identification level (MOREIRA et al., 2004).

Histopathological analysis also presents an efficient tool for diagnosis of ichthyobodiasis (URAWA et al., 1991; BRUNO et al., 
2006), but constitutes a non-sensitive technique in low parasitism intensity. Molecular methods of DNA extraction are more efficient (ISAKSEN et al., 2012) but less used and unpractical as a routine diagnostic method.

\section{Pathogenesis and clinical signs}

In Brazil this parasite does not cause significant mortality and in most cases low intensity infections were recorded in larvae and young fishes. Among the pathological alterations, it has been observed destruction of the epithelial cells due to parasite attachment (LOM \& DYKOVÁ, 1992), as well as degenerative and proliferative epithelial alterations with reduced mucus production (URAWA et al., 1991). Clinical signs are non-specific indicating respiratory difficulty and altered skin and gill color (URAWA et al., 1991; LOM \& DYKOVÁ, 1992).

\section{Other Parasites}

Entamoeba Casagrandi et Barbagallo, 1897

Entamoeba belongs to the amoebae group, moves and feeds by using extensions of its cytoplasm (pseudopods) and reproduces by binary fission. According to Ponce-Gordo and Martínez-Díaz (2010), the main morphological characteristic, which distinguishes Entamoeba from other genera, is the morphology of the nucleus. When cysts are mature, the different species of Entamoeba present a characteristic number of nuclei, which can be 1 belonging to bovis group, 4 to histolytica group, 8 to coli group and as gingivalis group when the number of cysts is not known. Analysis of Entamoeba can be made with histological sections of the affected organ, after fixing in $10 \%$ formalin solution and staining with iron haematoxylin or Heidenhain-Mallory Azan (ORIAS \& NOBLE, 1971). Smears of the intestine viewed under microscope with a drop of saline solution or iodine (BULLOCK, 1966) are used. Until the present, only Entamoeba pimelodi found in the intestine of yellow catfish Pimelodus clarias was observed parasitizing freshwater fishes in Brazil (CUNHA \& PENIDO, 1926).

Balantidium Clarapède et Lachmann, 1858

Members of Balantidium are unicellular and endocommensal parasites in the intestine of their hosts. Some of these ciliates appear to be host-specific, whereas others are generalists (BRUNO et al., 2006). Two developmental stages are present: the trophozoyte, flexible and covered by a row of longitudinal cilia reaching 40 to $140 \mu \mathrm{m}$ and the cyst, ovoid and measuring 40 to $60 \mu \mathrm{m}$ in diameter (BRUNO et al., 2006). Its horizontal transmission is made by oral and fecal via. In Brazil, Balantidium piscicola Geza, 1913 was found parasitizing caranha Piaractus brachypomus and mandi catfish Synodontis clarias (JUNIOR, 1913; PINTO, 1928).

Theileria Bettencourt, Franco et Borges, 1907

Members of Theileria spp. undergo exoerythrocytic merogony in the lymphocytes, erythroblasts and other cells of the internal organs, and this is followed by invasion of the erythrocytes by the merozoites, which may or may not reproduce (LAINSON, 2007). When division takes place, the parasite produces no more than four daughter cells (LEVINE, 1988 apud LAINSON, 2007). The elongated bacillary or bayonet forms are characteristic for
Theileria (BARNETT, 2012). In Brazil, Theileria electrophori is, so far, the only fish Theileria species reported from the viscera of a single juvenile of the electric eel Electrophorus electricus from the State of Pará, North Brazil. Air-dried smears of infected organs are fixed in absolute methyl alcohol and stained by Giemsa's method may be useful for accurate diagnosis of Theileria.

Calyptospora Overstreet, Hawkins et Fournie, 1984

These intracellular protozoan parasites are found in the liver and intestine of their hosts and have a heteroxenic life cycle transmitted by an infected crustacean ingested by a fish. In fish host, the oocysts (elliptical, ovoid or pear-shaped) present 4 sporocysts covered by a thin veil fixed by the presence of wall projections named sporopodia. Moreover, it presents a suture on the wall that do not divide the cell into two valves (EIRAS, 2013b).

Three species of Calyptospora were described parasitizing hepatocytes of Brazilian fishes: C. serrasalmi Cheung, Nigrelli and Ruggieri, 1986 from piranha Serrasalmus niger (CHEUNG et al., 1986); C. tucunarensis Békési and Molnár, 1991 from tucunaré Cichla ocellaris (BÉKÉSI \& MOLNÁR, 1991) and C. spinosa Azevedo, Matos and Matos, 1993 from joaninha Crenicichla lepidota (AZEVEDO et al. 1993). Coccidiosis by Calyptospora was found by Bonar et al. (2006) in Arapaima gigas exported to the United States. Albuquerque \& Brasil-Sato (2010) registered Calyptospora sp. in the liver and intestines of piaba-facão Triportheus guentheri and in the intestines of piaba Tetragonopterus chalceus. Additionally, Silva et al. (2012) have reported in piramutaba Brachyplatystoma vaillantii and Santiago et al. (2012) in tucunaré Cichla temensis. Fresh-mounted smears can be observed in light microscope. For histological analysis the infected organs are fixed in Davidson or $10 \%$ formalin solution and stained with hematoxylina and eosin (BÉKÉSI \& MOLNÁR, 1991; SANTIAGO et al., 2012). The oocysts can be studied by transmission electronic microscopy (AZEVEDO et al., 1993).

Haemogregarina Danylewsky, 1885, Cyrilia Lainson, 1981 and Desseria Siddall, 1995

These groups comprise several blood protozoan parasites (DINIZ et al., 2002; EIRAS, 2013b). They are commonly found in both erythrocytes and leukocytes of marine fishes (DAVIES, 1995), except for Cyrilia spp., which parasitize only the erythrocytes of freshwater fish. According to Davies et al. (2008), although most fish haemogregarine life cycles are unknown, fishes are likely to act as intermediate hosts, while leeches or gnathiid isopods are probably the definitive ones.

Cyrilia and Haemogregarina are both characterized by the presence of an intra-erythrocytic merogony phase in fish host, while in Desseria spp. this stage is not found (DAVIES et al., 2004). In Brazil, Haemogregarina was found parasitizing lungfish piramboia Lepidosiren paradoxa, mullet Mugil liza and sole Paralichthys orbignyanus (JEPPS, 1927; EIRAS et al., 1995; DAVIES et al., 2008), while Cyrilia lignieresi Laveran, 1906 was found in the blood of marbled swamp eel Synbranchus marmoratus (LAINSON 1981, 1992; DINIZ et al. 2002).

Eimeria Schneider, 1875

Frequently found parasitizing the intestinal wall of vertebrates including fish (MOLNAR et al., 2012). This group was originally confused with Calyptospora but according to Molnar (2006), differently from the latter, Eimeria does not have intermediate hosts 
in its life cycle. Sporocysts can be recognized by the presence of a "stieda" body (the opening of the sporocyst from where sporozoites goes out) (MOLNAR et al., 2012). According to Eiras (2013b) the degree of the lesions are variable. As for example, E. sardinae cause testis deformation and castration in Sardina pilchardus. Up to now, Eimeria sp. was only observed in the intestine of lungfish L. paradoxa in the State of Pará, North Brazil by Lainson \& Ribeiro (2006).

Nyctotherus Leidy, 1849 and Rhynchodinium paradoxum Cunha et Penido, 1927

Ciliated Nyctotherus is present in digestive tract of insects, amphibians and fishes. The trophozoite has around $200 \mu \mathrm{m}$, is oval and provided with cilia arranged in longitudinal rows and a cytostome located in the middle of the body (THATCHER, 2006; EIRAS, 2013a); cytopharynx - a duct that communicates cytostome with the interiorof the parasite- with undulating membrane. Great macronucleus, triangular and located at the anterior end of the body.

According to Thatcher (2006), these protozoans do not cause severe pathology and can be considered as endocommensals (EIRAS, 2013a). In Brazil, it was observed in P. brachypomus, Acestrorhampus sp. and P. clarias (PINTO, 1928).

Rhynchodinium paradoxum shows elongated and cylindershaped body, bean-shaped macronucleus located at the anterior end of the body. Cilia are long but absent on the posterior end of the body (THATCHER, 2006). This protozoan was found in the intestine of granulated catfish abotoado Pterodoras granulosus (CUNHA \& PENIDO, 1927).

\section{Tetrabymena Furgason, 1940}

Tetrahymena is considered an important pathogenic agent to ornamental freshwater fish where it may cause severe mortalities (BRUNO et al., 2006) (Figure 10). This protozoan has a pearshaped body covered by a row of cilia, besides macronucleus and micronucleus. According to Bruno et al. (2006), these ciliates do not form cysts and studies suggest that Tetrahymena penetrates the host epithelium (especially where there are wounds) reaching the blood and parasitizing the gills, kidney, eyes and brain (EIRAS, 2013a).



Figure 10. Tetrahymena sp. from the skin of guppy (Poecilia sp.) observed in light microscope at $40 \mathrm{x}$ magnification.
In Brazil, this parasite was found parasitizing the butterfly fish Carnegiella strigata (TAVARES-DIAS et al., 2010), and can be commonly found parasitizing guppies. Cutaneous infestation by Tetrahymena causes scaleness, whitish lesions on the skin and opportunistic secondary infection by bacteria.

\section{Hexamita Dujardin, 1838}

Members of Hexamita possess oval body, bilateral symmetry, provided by four pairs of flagella, three anterior for locomotion and one posterior, besides two spherical nuclei located at the anterior end (ROTHENBACHER \& BOHL, 1975; FOIN, 2005). They are opportunistic endoparasites of the intestinal tract of wild and farmed marine, freshwater and ornamental fishes in tropical and temperate waters (ROTHENBACHER \& BOHL, 1975; EIRAS, 1994; FRANCIS-FLOYD \& REED, 1994; FOIN, 2005). It can also be found in the swimbladder, liver, spleen, blood, kidney, and heart of hosts (FOIN, 2005). After analysis of 7,139 fish specimens between the years 1987 and 1990, Békési (1992) registered the presence of Hexamita in Brazil from the intestine of Prochilodus brevis (syn. P. cearensis). These parasites present a monoxenic life cycle; the pear-shaped trophozoites change to spherical before cellular division (WOO, 2006). They can be horizontaly transmitted by the releasing of trophozoites and oocysts into the water from the fish feces that will be ingested by other hosts (LOM \& DYKOVÁ, 1992; FOIN, 2005). The diagnosis can be made by analysing the feces of infected fish under high magnification (KLINGER \& FRANCIS-FLOYD, 1998; FOIN, 2005).

\section{Distribution of Parasites in Brazil}

Several protozoan parasites of fishes have been reported in national territory, as a result of efforts of Brazilian researchers from different localities. Nevertheless, unpublished data of the present authors indicate that much more observations are yet to be reported as shown in Figure 11.

\section{Attention on the Control Strategies}

The use of chemicals in order to control protozoan parasites can be, sometimes, difficult to administer, costly, not completely efficient and even environmentally hazardous. Dozens of protocols used in many other countries for tropical and temperate fishes have been adapted to fish farms in Brazil with no scientific criteria. In fact, if applied erroneously, it may cause environmental degradation such as impairment of water quality ( $\mathrm{pH}$ and dissolved oxygen alterations can lead to great fish mortality), besides the fact that several chemoterapeutics employed are corrosive, carcinogenic or even explosive. On this view, they must be manipulated with PPE's (Personel Protection Equipment) and special care. Nevertheless, in field practices it is usually observed low knowledge when employing these techniques. Prophylactic measurements or immunoprophylaxis adopted in the fish farms and ornamental industry are important tools to minimize the effects of parasitism and to estimulate the fish immune system (MARTINS et al., 2011).

In order to control outbreaks of diseases in fish farms it is fundamental to first characterize carefully the hygienic-sanitary state of the facility. This includes being aware of disease diagnosis 

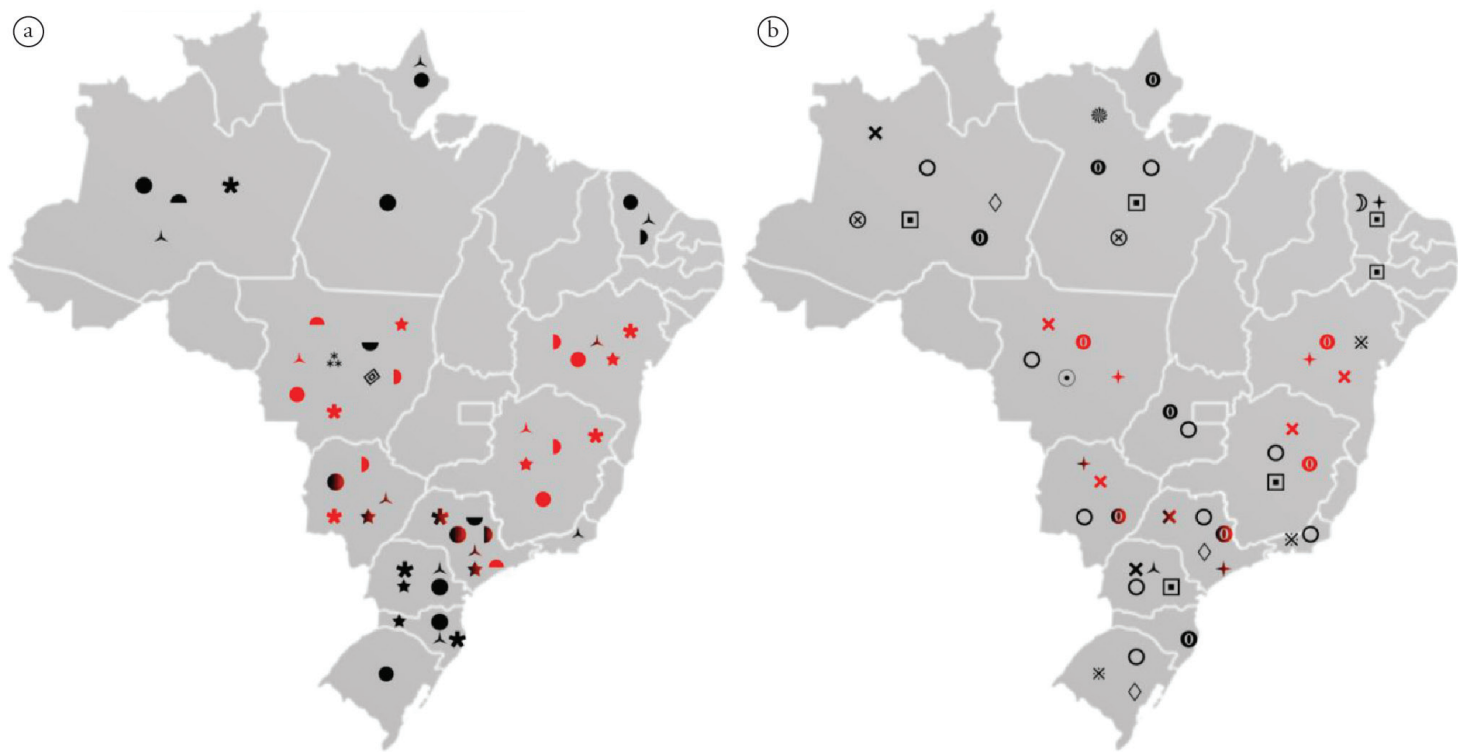

Figure 11. Geographical distribution of (a) ciliated protozoan and (b) other protozoan parasite groups of fishes from Brazil. Symbols indicate the register of the below-mentioned species: $\odot$ Entamoeba pimelodi; $※$ Amyloodinium; + Cryptobia; D Hexamita; $\times$ Ichthyobodo; 0 Piscinoodinium;


$\star$ Epistylis; Ichthyophthirius multifliis; - Nyctotherus piscicola; $\diamond$ Rynchodinium paradoxum; $\bullet$ Tetrahymena and $\curlywedge$ Trichodinidae. Colour black indicates previous reports; colour red indicates unpublished data from the present authors.

history, recognition of pathogen dispersal and/or transmission modes involved. The use of chemotherapeutics cannot be linked only when an outbreak of mortality occurs, in which treatment is employed as a rescue measure to reduce the economic losses. Such products must be applied strategically in each rearing phases in order to have the best fish response, with lowest environmental impact and safety to the operating person.

Disease control in hatcheries that produce fingerlings is a key point to reach the high sanitary quality and regular production (PÁDUA \& CRUZ, 2014). In these farms, transmission of diseases from the broodstock to eggs, larvae and fingerlings deserves special attention. Efforts to control diseases must be concentrated on these units, which represent the beginning of the production cycle.

In tilapia hatcheries where the eggs are collected from the mouth, it may be necessary to disinfect them before storage in incubators. The use of Chloramine- $\mathrm{T}$ is an efficient measure for disinfecting eggs against viruses, bacteria, fungi and parasites found in this process. In order to proceed, the use of small capacity circulating systems $(200-1,000 \mathrm{~L})$ should be implemented so as to supply 2 to 6 incubators that will recirculate water with $30 \mathrm{mg} / \mathrm{L}$ of Chloramine-T, during 10 to $20 \mathrm{~min}$ of exposition. It is important to assure that water will circulate inside a mechanical filtration system with the aid of an acrylic filter mat. In this case, it is worth mentioning that the use of activated carbon elements or other substances with adsorption effects is not recommended, since they could kidnap the molecule of the drug used for disinfection.

Adequate management include not handling fish when abiotic factors such as water temperature and $\mathrm{pH}$ are exceeding limits generally considered safe for the fish species, avoid translocation of fingerlings from one place to another without proper care, always use good quality feeds, monitor regularly the quality of the water entering the farm, avoid water sharing among ponds and disinfect fish handling equipment. After that, it is necessary to adopt other measures of biosecurity to ensure larvae remain free of parasites during subsequent rearing phases. For such, it is important to sectorize fish farm facilities, thus delimitating areas for equipments and for passage of employees. Other important measures to avoid disease dissemination include preventing entry of wild fish in the farm (this can be done using screens in the water supply canal), implementing sanitary barriers such as cleaning and disinfecting ponds, using a quarantine tank, depurating fish before transport and using wetlands in the water supply canal.

Wetlands macrophytes such as Eichhornia spp. (Figure 12) can be considered an efficient tool to contain dispersion of resistant forms of parasites, such as eggs and resistent cysts into the farm, as well as to provide a huge surface area for attached microbial growth. However, one must establish a routine for renewal of these aquatic plants so that the saturation capacity of retention of particles in its submerged roots does not occurs. To this end, it must be performed the removal of adult plants, or under the senescent stage, every 15 to 45 days, varying according to the season and the amount of suspended material in the water.

After storage of fingerlings in a farm destinated to fish fattening, the use of sanitary measures may be expensive and sometimes operationally difficult. On the other hand, the implementation of sanitary measures in hatcheries is more economic and efficient in suppressing or erradicating the disease (PÁDUA \& CRUZ, 2014). Similar to that found in industrial pig and poultry farming, young fish should be sent to growing units in a good health status and possibly vaccinated, minimizing thus parasite hazard to an acceptable level. It must be emphasized that it is complex to achieve fish completely negative for parasites and so prophylaxis and best management practices are the best ways of achieving adequate health status of farmed fish (BOYD et al., 2008). 


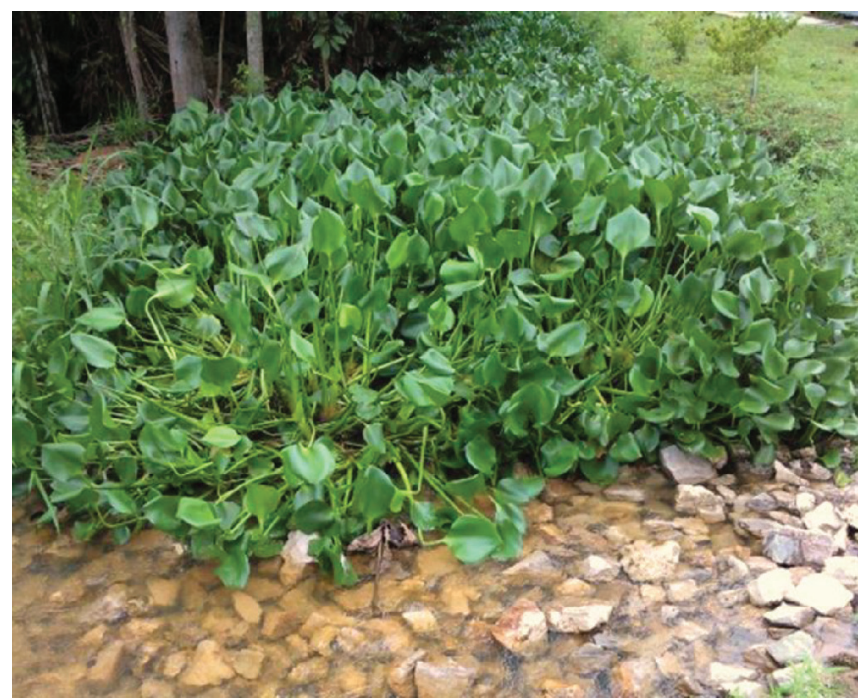

Figure 12. Constructed wetland in freshwater fish farm for use as a sanitary barrier and water cleaning.

\section{Acknowledgements}

The authors thank Fundect (Process no 23/200.202/2010 and 10/14490-1) for financial support and CNPq (National Council of Scientific and Technological Development) for grant to M.L. Martins (302493/2010-7) and financial support (472598/2011-2); Roney Nogueira de Menezes Filho (Aquivet Saúde Aquática) for collaboration on diagnostic information from the field and control approach used in fingerlings hatchery-farming; Wellington Correa Silva and Fernando Franceschini Macedo (Raçóes VB) for valorous information on the protozoan occurrence in native fish from the Central-North region of Brazil; Dra. Ana Paula de Araújo (Acquapiscis) for information of parasitic protozoan in marine fish; Dra. Márcia Mayumi Ishikawa (Embrapa Agropecuária Oeste) for information on native fish protozoosis inluding bait fish.

\section{References}

Abreu PC, Robaldo RB, Sampaio LA, Bianchini A, Odebrecht C. Recurrent amyloodiniosis on broodstock of the Brazilian flounder Paralichthys orbignyanus: dinospore monitoring and prophylactic measures. $J$ World Aquac Soc 2005; 36(1): 42-50. http://dx.doi.org/10.1111/j.1749-7345.2005. tb00129.x.

Albuquerque MC, Carvalho Brasil-Sato M. First report of Calyptospora sp. (Apicomplexa, Calyptosporidae) in forage characid fish from the Três Marias Reservoir, São Francisco Basin, Brazil. Eur J Protistol 2010; 46(2): 150-152. http://dx.doi.org/10.1016/j.ejop.2009.12.005. PMid:20163938

Azevedo C, Matos P, Matos E. Morphological data of Calyptospora spinosa n. sp. (Apicomplexa, Calyptosporidae) parasite of Crenicichla lepidota HECKEL, 1840 (Teleostei) from Amazon river. Eur J Protistol 1993; 29(2): 171-175. http://dx.doi.org/10.1016/S0932-4739(11)80270-1. PMid:23195539

Barnett SF. Theileria. In: Kreir J (Ed.). Parasitic Protozoa: Babesia, Theileria, Myxosporida, Microsporida, Bartonellaceae, Anaplasmataceae, Ehrlichia, and Pneumocystis. Elsevier; 2012. p. 77-92. vol. 4.
Basson L, Van As JG. Trichodinidae and other ciliophorans (Phylum Ciliophora). In: Woo PTK. Fish diseases and disorders. 2nd ed. Cab International; 2006. p. 154-182. vol. 1. Protozoan and Metazoan infections.

Békési L. Evaluation of data on ichthyopathological analyses in the Brazilian Northeast. Cienc Cult 1992; 44(6): 400-403.

Békési L, Molnár K. Calyptospora tucunarensis n. sp. (Apicomplexa: Sporozoea) from liver of tucunare Cichla ocellaris in Brazil. Syst Parasitol 1991; 18(2): 127-132. http://dx.doi.org/10.1007/BF00017665.

Bittencourt LS, Pinheiro DA, Cárdenas MQ, Fernandes BM, Tavares-Dias M. Parasites of native Cichlidae populations and invasive Oreochromis niloticus (Linnaeus, 1758) in tributary of Amazonas River (Brazil). Rev Bras Parasitol Vet 2014; 23(1): 44-54. http://dx.doi.org/10.1590/S198429612014006. PMid:24728360

Bonar CJ, Poynton SL, Schulman FY, Rietcheck RL, Garner MM. Hepatic Calyptospora sp. (Apicomplexa) infection in a wild-born, aquarium-held clutch of juvenile arapaima Arapaima gigas (Osteoglossidae). Dis Aquat Organ 2006; 70(1-2): 81-92. http://dx.doi.org/10.3354/dao070081. PMid:16875394

Bondad-Reantaso MG, Subasinghe RP, Arthur JR, Ogawa K, Chinabut $S$, Adlard R et al. Disease and health management in Asian aquaculture. Vet Parasitol 2005; 132(3-4): 249-272. http://dx.doi.org/10.1016/j. vetpar.2005.07.005. PMid:16099592

Boyd CEB, Lim C, Queiroz J, Salie K, De Wet L, McNevin A. Best management practices for responsible aquaculture. Washington: Aquaculture Collaborative Research Support Program; 2008. 47 p.

Bruno DW, Nowak B, Elliott DG. Guide to the identification of fish protozoan and metazoan parasites in stained tissue sections. Dis Aquat Organ 2006; 70(1-2): 1-36. http://dx.doi.org/10.3354/dao070001. PMid:16875388

Bullock WL. Entamoeba gadi sp. n. from the rectum of the pollock, Pollachius virens (L., 1758), with some observations on its cytochemistry. J Parasitol 1966; 52(4): 679-684. http://dx.doi.org/10.2307/3276429. PMid:4226197

Cecchini S, Saroglia M, Terova G, Albanesi F. Detection of antibody response against Amyloodinium ocellatum (Brown, 1931) is serum of naturally infected European sea bass by an enzyme-linked immunosorbent assay (ELISA). Bull Eur Assoc Fish Pathol 2001; 21(3): 104-108.

Cheung PJ, Nigrelli RF, Ruggieri GD. Calyptospora serrasalmi sp. nov. (Coccidia: Calyptosporidae) from liver of the black piranha, Serrasalmus niger Schomburgk. J Aquaricult Aquat Sci 1986; 4(3): 54-57.

Cruz-Lacierda ER, Maeno Y, Pineda AJT, Matey VE. Mass mortality of hatchery-reared milkfish (Chanos chanos) and mangrove red snapper (Lutjanus argentimaculatus) caused by Amyloodinium ocellatum (Dinoflagellida). Aquaculture 2004; 236(1-4): 85-94. http://dx.doi org/10.1016/j.aquaculture.2004.02.012.

Cunha AM, Penido JCN. Entamoeba pimelodin. sp., parasite d'un poisson d'eau douce. C R Soc Biol Paris 1926; 95: 1010-1011.

Cunha AM, Penido JCN. Rynchodinium paradoxum n. gen. protozoaire parasite dúm poissson déau douce. C R Soc Biol Paris 1927; 97(36): 1793-1794.

D'agosto M, Serra-Freire NM. Estádios evolutivos de tripanossomas de Hipostomus punctatus Valenciennes (Osteichthyes, Loricariidae) em infecção natural de Batracobdella gemmata Blanchard (Hirudinea, Glossiphoniidae). Rev Bras Zool 1993; 10(3): 417-426. 
Davies AJ. The biology of fish haemogregarines. Adv Parasitol 1995; 36: 117-203. http://dx.doi.org/10.1016/S0065-308X(08)60491-1.

Davies AJ, Smit NJ, Hayes PM, Seddon AM, Wertheim D. Haemogregarina bigemina (Protozoa: Apicomplexa: Adeleorina) - past, present and future. Folia Parasitol 2004; 51(2-3): 99-108. http://dx.doi.org/10.14411/ fp.2004.015. PMid:15357389

Davies AJ, Amado LL, Cook RT, Bianchini A, Eiras JC. Potential environmental and host gender influences on prevalence of Haemogregarina platessae (Adeleorina:Haemogregarinidae) and suspected Haemohormidium terraenovae (incertae sedis) in Brazilian flounder from the Patos Lagoon Estuary, southern Brazil. Folia Parasitol 2008; 55(3): 161-170. http:// dx.doi.org/10.14411/fp.2008.023. PMid:19202674

Diniz JA, Silva EO, Souza W, Lainson R. Some observations on the fine structure of trophozoites of the haemogregarine Cyrilia lignieresi (Adeleina: Haemogregarinidae) in erythrocytes of the fish Synbranchus marmoratus (Synbranchidae). Parasitol Res 2002; 88(7): 593-597. http:// dx.doi.org/10.1007/s00436-002-0603-x. PMid:12107449

Durborow RM. Protozoan parasites. Southern Regional Aquaculture Center; 2003. vol. 4701.

Eiras JC. Elementos de ictioparasitologia. Porto: Fundação Engenheiro Antônio de Almeida; 1994.

Eiras JC. Ciliophora. In: Pavanelli GC, Takemoto RM, Eiras JC, editors. Parasitologia de peixes de água doce do Brasil. Maringá: Eduem; 2013a. p. 233-245.

Eiras JC. Apicomplexa. In: Pavanelli GC, Takemoto RM, Eiras JC, editors. Parasitologia de peixes de água doce do Brasil. Maringá: Eduem; 2013b. p. 217-231.

Eiras JC, Ranzani-Paiva MJT, Davies AJ. Observations on Haemogregarina mugili (Apicomplexa) and Trypanosoma froesi (Sarcomastigophora) from the blood of Mugil platanus Günther, 1880 (Pisces: Mugilidae) in Brazil. Res Rev Parasitol 1995; 55(3): 173-176.

Eiras JC, Takemoto RM, Pavanelli GC, Luque JL. Checklist of protozoan parasites of fishes from Brazil. Zootaxa 2012; 3221: 1-25.

El-Tantawy SAM, Reda ESA, Abdel-Aziz A, Abou El-Nour MF, Rady I. Apiosoma spp. and Scopulata epibranchialis infesting Nile perch fish Lates niloticus in Dakahlia Province, Egypt. NY Sci J 2013; 6(6): 111-118.

Fernandes NM, Sartini B, Dias RJ, D’Agosto M. Quantitative study of Trichodina heterodentata (Ciliophora: Mobilia) infrapopulations infesting tadpoles of a Brazilian endemic toad Rhinella pombali (Anura: Bufonidae). Zoologia 2011; 28(6): 777-783. http://dx.doi.org/10.1590/ S1984-46702011000600011.

Ferreira ML, Avenant-Oldewage A. Notes on the occurrence of Trypanosoma sp. (Kinetoplastida: Trypanosomatidae) in freshwater fishes from South Africa. Onderstepoort J Vet Res 2013; 80(1): 529. http://dx.doi.org/10.4102/ ojvr.v80i1.529. PMid:23718161

Foin AA. Parasites et parasitoses des poissons d'ornement d'eau douce: aide au diagnostic et propositions de traitement [Tese]. Maisons-Alfort: École Nationale Veterinaire d' Alfort; 2005.

Francis-Floyd R, Reed P. Management of Hexamita in ornamental cichlids [online]. Florida: Institute of Food and Agricultural Sciences, University of Florida; 1994 [cited 2014 Jan 23]. Available from: http:// www.extension.org/mediawiki/files/0/02/Management_of_hexamita_ in_ornamental_cichlids.pdf.

Francis-Floyd R, Floyd MR. Amyloodinium ocellatum: an important parasite of cultured marine fish [online]. Florida: Southern Regional Aquaculture
Center (SRAC), Institute of Food and Agricultural Sciences, University of Florida; 2011 [cited 2014 Jan 30]. Available from: http://agrilifecdn.tamu. edu/fisheries/files/2013/09/SRAC-Publication-No.-4705-Amyloodiniumocellatum-an-Important-Parasite-of-Cultured-Marine-Fish.pdf.

Ghiraldelli L, Martins ML, Adamante WB, Yamashita MM. First record of Trichodina compacta Van as and Basson, 1989 (Protozoa: Ciliophora) from cultured Nile tilapia in the state of Santa Catarina, Brazil. Int J Zool Res 2006; 2(4): 369-375. http://dx.doi.org/10.3923/ijzr.2006.369.375.

Guerra-Santos B. Uso do medicamento homeopático sulphur no controle do Amyloodinium sp. em bijupirá (Rachycentron canadum Linnaeus, 1766) [Tese]. Salvador: Universidade Federal da Bahia; 2011.

Guerra-Santos B, Albinati RC, Moreira ELT, Lima FW, Azevedo TM, Costa DSP, et al. Parâmetros hematológicos e alteraçóes histopatológicas em bijupirá (Rachycentron canadum Linnaeus, 1766) com amyloodiniose. Pesq Vet Bras 2012; 32(11): 1184-1190. http://dx.doi.org/10.1590/ S0100-736X2012001100019.

Hazen TC, Raker ML, Esch GW, Fliermans CB. Ultrastruct of red-sore lesions on largemouth bass (Micropterus salmoides): associattion of the ciliate Epistylis sp. and the bacterium Aeromonas hydrophila. J Protozool 1978; 25(3 Pt 2):351-355. http://dx.doi.org/10.1111/j.1550-7408.1978. tb03901.x. PMid:102785

Hussein ANA, Rabie SA, Mohammed NE, Hussein NM. Light and scanning electron microscopic studies of trypanosomes parasites infecting freshwater fishes in Qena Governorate, Egypt. Egypt Acad J Biolog Sci 2010; 2(1): 17-31.

Isaksen TE, Karlsbakk E, Repstad O, Nylund A. Molecular tools for the detection and identification of Ichthyobodo spp. (Kinetoplastida), important fish parasites. Parasitol Int 2012; 61 (4): 675-683. http://dx.doi. org/10.1016/j.parint.2012.07.006. PMid:22824336

Isaksen TE. Ichthyobodo infections on farmed and wild fish [Tese]. Bergen: University of Bergen; 2013.

Ishikawa MM, Pádua SB, Ventura AS, Jerônimo GT, Russo MR, CarrijoMauad JR, et al. Biologia e estratégias na sanidade de alevinos de bagres carnivoros. Embrapa Agropecuária Oeste; 2012. p. 1-35. Documentos 115. </bok>.

Jepps MW. Note on a haemogregarine in Lepidosiren paradoxa. Parasitology 1927; 19(3): 285-287. http://dx.doi.org/10.1017/S0031182000005722.

Jerônimo GT, Speck GM, Cechinel MM, Gonçalves ELT, Martins ML. Seasonal variation on the ectoparasitic communities of Nile tilapia cultured in three regions in southern Brazil. Braz J Biol 2011; 71(2): 365-373. http://dx.doi.org/10.1590/S1519-69842011000300005. PMid:21755153

Junior GE. Ueber Organisationsverhältnisse von Nyctotherus piscicola (Daday). Arch Protistenkd 1913; 29: 364-386.

Kazubski SL, Migala K. Studies on the distinctness of Chilodonella cyprini (Moroff) and Ch. Hexasticha (Kiernik) (Chlamydodontidae, Gymnostomatida), ciliate parasite of fishes. Acta Protozool 1974; 13: 9-40.

Klinger RE, Francis-Floyd R. Introduction to freshwater fish parasites [online]. Florida: Institute of Food and Agricultural Sciences, University of Florida; 1998. CIR716. Available from: http://edis.ifas.ufl.edu/pdffiles/ FA/FA04100.pdf.

Kozloff EN. Redescription of Cryptobia helicis Leidy, 1846 (Kinetoplasta: Bodonea: Cryptobiidae), disposition of flagellates mistakenly assigned to this species, and description of a new species from a North American pulmonate snail. Acta Protozool 2004; 43: 123-132. 
Kuperman BI, Matey VE, Barlow SB. Flagellate Cryptobia branchialis (Bodonida: Kinetoplastida), ectoparasite of tilapia from the Salton Sea. Hydrobiologia 2002; 473(1-3): 93-102. http://dx.doi.org/10.1023/A:1016577516848.

Lainson R. On Cyrilia gomesi (Neiva and Pinto, 1926) gen. nov. (Haemogregarinidae) and Trypanosoma bourouli Neiva and Pinto, in the fish Synbranchus marmoratus: simultaneous transmission by the leech Haementeria lutzi. In: Canning EU, editor. Parasitological topics. London: Society of Protozoologists; 1981. p. 150-158. Special Publication vol. 1.

Lainson R. A protozoologist in Amazonia: neglected parasites, with particular reference to members of the Coccidia (Protozoa, Apicomplexa). Cienc Cult 1992; 44(2-3): 81-93.

Lainson R, Ribeiro L. Eimeria lepidosirenis n.sp. (Apicomplexa:Eimeriidae) of the South American lungfish Lepidosiren paradoxa (Osteichthyes:Dipnoi) from Amazonian Brazil. Mem Inst Oswaldo Cruz 2006; 101(3): 327-329. http://dx.doi.org/10.1590/S0074-02762006000300018. PMid:16862331

Lainson R. Theileria electrophori n.sp., a parasite of the electric eel Electrophorus electricus (Osteichthyes: Cypriniformes: Gymnotidae) from Amazonian Brazil. Mem Inst Oswaldo Cruz 2007; 102(2): 155-157. http:// dx.doi.org/10.1590/S0074-02762007000200005. PMid:17426878

Landsberg JH, Steldlnger KA, Blakesley BA, Zondervan RL. Scanning electron microscope study of dinospores of Amyloodinium cf. ocellatum, a pathogenic dinoflagellate parasite of marine fish, and comments on its relationship to the Peridiniales. Dis Aquat Organ 1994; 20(1): 23-32. http://dx.doi.org/10.3354/dao020023.

Levy MG, Poore MF, Colorni A, Noga EJ, Vandersea MW, Litaker RW. A highly specific PCR assay for detecting the fish ectoparasite Amyloodinium ocellatum. Dis Aquat Organ 2007; 73(3): 219-226. http:// dx.doi.org/10.3354/dao073219. PMid:17330741

Li M, Wang J, Zhu D, Gu Z, Zhang J, Gong X. Study of Apiosoma piscicola (Blanchard 1885) occurring on fry of freshwater fishes in Hongze, China with consideration of the genus Apiosoma. Parasitol Res 2008; 102(5): 931-937. http://dx.doi.org/10.1007/s00436-007-0856-5. PMid:18247054

Li M, Li W, Ge X, Wang C, Zhang L, Huang F, et al. First report of Epistylis unioi Gong 1986 (Sessilida: Epistylididae) infecting fry of Pelteobagrus fulvidraco in Hubei, China. Zootaxa 2012; 3556: 80-88.

Lom J. A contribution to the systematics and morphology of endoparasitic trichodinids from amphibians, with a proposal of uniform specific characteristics. J Protozool 1958; 5(4): 251-263. http://dx.doi. org/10.1111/j.1550-7408.1958.tb02563.x.

Lom J, Schubert G. Ultrastructural study of Piscinoodinium pillulare (Schäperclaus, 1954) Lom, 1981 with special emphasis on its attachment to the fish host. J Fish Dis 1983; 6(5): 411-428. http://dx.doi. org/10.1111/j.1365-2761.1983.tb00096.x.

Lom J, Dyková I. Protozoan parasites of fishes. Amsterdam: Elsevier Science; 1992. 315 p. vol. 26. Developments in Aquaculture and Fisheries Science.

Martins ML, Morais FR, Fujimoto RY, Onaka EM, Nomura DT, Silva $\mathrm{CAH}$, et al. Parasitic infections in cultivated freshwater fishes a survey of diagnosticated cases from 1993 to 1998. Rev Bras Parasitol Vet 2000; 9(1): 23-28. PMid:24728357.

Martins ML, Moraes JRE, Andrade PM, Schalch SHC, Moraes FR. Piscinoodinium pillulare (Schäperclaus, 1954) Lom, 1981 (Dinoflagellida) infection in cultivated freshwater fish from the northeast region of Sao Paulo State, Brazil. Parasitological and pathological aspects. Braz J Biol 2001; 61(4): 639-644. http://dx.doi.org/10.1590/S1519-69842001000400013. PMid:12071320
Martins ML, Marchiori N, Nunes G, Rodrigues MP. First record of Trichodina heterodentata (Ciliophora: Trichodinidae) from channel catfish, Ictalurus punctatus cultivated in Brazil. Braz J Biol 2010a; 70(3): 637-644. http://dx.doi.org/10.1590/S1519-69842010000300022. PMid:20730352

Martins ML, Azevedo TMO, Ghiraldelli L, Bernardi N. Can the parasitic fauna on Nile tilapias be affected by different production systems? An Acad Bras Cienc 2010b; 82(2): 493-500. http://dx.doi.org/10.1590/ S0001-37652010000200024. PMid:20563429

Martins ML, Shoemaker CA, Xu D-H, Klesius PH. Effect of parasitism on vaccine efficacy against Streptococcus iniae in Nile tilapia. Aquaculture 2011; 314(1-4): 18-23. http://dx.doi.org/10.1016/j.aquaculture.2011.01.022.

Martins ML, Marchiori N, Roumbedakis K, Lami F. Trichodina nobilis Chen, 1963 and Trichodina reticulata Hirschmann et Partsch, 1955 from ornamental freshwater fishes in Brazil. Braz J Biol 2012; 72(2): 281-286. http://dx.doi.org/10.1590/S1519-69842012000200008. PMid:22735135

Martins ML, Marchiori NC, Garcia P. Doenças parasitárias do jundiá. In: Barcellos LJG, Fagundes M, Ferreira D. Workshop sobre jundiá: história e perspectivas. Passo Fundo: UPF; 2013. p. 184-221.

Maslov DA, Podlipaev SA, Lukes J. Phylogeny of the kinetoplastida: taxonomic problems and insights into the evolution of parasitism. Mem Inst Oswaldo Cruz 2001; 96(3): 397-402. http://dx.doi.org/10.1590/ S0074-02762001000300021. PMid:11313652

Miranda LH, Marchiori N, Alfaro CR, Martins ML. First record of Trichodina heterodentata (Ciliophora: Trichodinidae) from Arapaima gigas cultivated in Peru. Acta Amazonica 2012; 42(3): 433-438. http:// dx.doi.org/10.1590/S0044-59672012000300016.

Molnár K. Phylum Apicomplexa. In: Woo PTK, editor. Fish diseases and disorders: protozoan and metazoan infections. Cambridge: CABI Publishing; 2006. p. 183-204.

Molnár K, Ostoros G, Dunams-Morel D, Rosenthal BM. Eimeria that infect fish are diverse and are related to, but distinct from, those that infect terrestrial vertebrates. Infect Genet Evol 2012; 12(8): 1810-1815. http://dx.doi.org/10.1016/j.meegid.2012.06.017. PMid:22824419

Montgomery-Brock D, Sato VT, Brock JA, Tamaru CS. The application of hydrogen peroxide as a treatment for the ectoparasite Amyloodinium ocellatum (Brown 1931) on the Pacific threadfin Polydactylus sexfilis. J World Aquac Soc 2001; 32(2): 250-254. http://dx.doi.org/10.1111/j.1749-7345.2001. tb01103.x.

Moraes FR, Martins ML. Condiçôes predisponentes e principais enfermidades de teleósteos em piscicultura intensiva. In: Cyrino JEP, Urbinati EC, Fracalossi DM, Castagnolli N, editors. Tópicos especiais em piscicultura de água doce tropical intensiva. São Paulo: TecArt; 2004 p. 343-383.

Moreira CB, Hashimoto GSO, Rombenso AN, Candiotto FB, Martins ML, Tsuzuki MY. Outbreak of mortality among cage-reared cobia (Rachycentron canadum) associated with parasitism. Rev Bras Parasitol Vet 2013; 22(4): 588-591. http://dx.doi.org/10.1590/S1984-29612013000400021. PMid:24473886

Moreira D, López-García P, Vickerman K. An updated view of kinetoplastid phylogeny using environmental sequences and a closer outgroup: proposal for a new classification of the class Kinetoplastea. Int J Syst Evol Microbiol 2004; 54(Pt 5): 1861-1875. http://dx.doi.org/10.1099/ijs.0.63081-0. PMid:15388756

Noga EJ, Levy MG. Phylum Dinoflagellata. In: Woo PTK, editor. Fish disease: diagnosis and treatment. 2nd ed. CABI International; 2006. p. 16 
Noga EJ. Propagation in cell culture of the dinoflagellate Amyloodinium, an ectoparasite of marine fishes. Science 1987; 236(4806): 1302-1304. http://dx.doi.org/10.1126/science.236.4806.1302. PMid:17770332

Orias JD, Noble ER. Entamoeba nezumia sp. n. and other parasites from a North Atlantic fish. J Parasitol 1971; 57(5): 945-947. http://dx.doi. org/10.2307/3277840. PMid:5133900

Pádua SB, Martins ML, Varandas DN, Dias Neto J, Ishikawa MM, Pilarski F. Tricodinídeos: quem são e o que eles podem causar nos peixes. Panorama da Aquicultura 2011a; 121(127): 22-29.

Pádua SB, Ishikawa MM, Satake F, Jerônimo GT, Pilarski F. First record of Trypanosoma sp. (Protozoa: Kinetoplastida) in tuvira (Gymnotus aff. inaequilabiatus) in the Pantanal wetland, Mato Grosso do Sul State, Brazil. Rev Bras Parasitol Vet 2011b; 20(1): 85-87. http://dx.doi.org/10.1590/ S1984-29612011000100019. PMid:21439241

Pádua SB, Menezes Filho RN, Dias Neto J, Ishikawa MM, Jerônimo GT, Martins ML, et al. Epistilíase: uma doença emergente no Brasil. Panor. Aquic. 2012a; 22(129): 22-31.

Pádua SD, Ishikawa MM, Kasai RYD, Jerônimo GT, Carrijo-Mauad JR. Parasitic infestations in hybrid surubim catfish fry (Pseudoplatystoma reticulatum $x$ P. corruscans). Rev Bras Med Vet 2012b; 34(3): 235-240.

Pádua SB, Martins ML, Carraschi SP, Cruz C, Ishikawa MM. Trichodina heterodentata (Ciliophora: Trichodinidae): a new parasite for Piaractus mesopotamicus (Pisces: Characidae). Zootaxa 2012c; 3422: 62-68.

Pádua SB, Martins ML, Carrijo-Mauad JR, Ishikawa MM, Jerônimo GT, Dias-Neto J, et al. First record of Chilodonella hexasticha (Ciliophora: Chilodonellidae) in Brazilian cultured fish: a morphological and pathological assessment. Vet Parasitol 2013a; 191(1-2): 154-160. http:// dx.doi.org/10.1016/j.vetpar.2012.07.030. PMid:22902259

Pádua SB, Ishikawa MM, Ventura AS, Jerônimo GT, Martins ML, Tavares LER. Brazilian catfish parasitized by Epistylis sp. (Ciliophora, Epistylididae), with description of parasite intensity score. Parasitol Res 2013b; 112(1): 443-446. http://dx.doi.org/10.1007/s00436-012-30695. PMid:22890898

Pádua SB, Jerônimo GT, Ishikawa MM, Belo MAA, Martins ML, Pelisari T, et al. Parasitological assessment and host-parasite relationship in farmed cachara catfish fingerlings Pseudoplatystoma reticulatum (Eigenmann \& Eigenmann 1889). Neotrop Helminthol 2014; 8(1): 37-45.

Pádua SB, Cruz C. Health challenges in tilapia culture in Brazil. Aquaculture Asia Pacific 2014; 10(2): 37-39.

Palm HW, Dobberstein RC. Occurrence of trichodinid ciliates (Peritricha: Urceolariidae) in the Kiel Fjord, Baltic Sea, and its possible use as a biological indicator. Parasitol Res 1999; 85(8-9): 726-732. http://dx.doi. org/10.1007/s004360050622. PMid:10431740

Pereira JC, Abrantes I, Martins I, Barata J, Frias P, Pereira I. Ecological and morphological features of Amyloodinium ocellatum occurrences in cultivated gilthead seabream Sparus aurata L.: a case study. Aquaculture 2011; 310(3): 289-297. http://dx.doi.org/10.1016/j.aquaculture.2010.11.011.

Pinto C. Myxosporideos e outros protozoários intestinais de peixes observados na América do Sul. Arch Inst Biol 1928; 1: 102-136.

Pinto HA, Wieloch AH, Melo AL. Uma nova espécie de Trichodina Ehrenberg, 1838 (Ciliophora: Trichodinidae) em Biomphalaria schrammi (Crosse, 1864) (Mollusca: Planorbidae). Lundiana 2006; 7(2): 121-124.

Pinto E, Garcia AM, Figueiredo HCP, Rodrigues MP, Martins ML. First record of Tripartiella sp. (Ciliophora: Peritrichia) in Pseudoplatystoma corruscans (Osteichthyes: Pimelodidae) cultured in the state of Mato
Grosso do Sul, Brazil, with the description of a new species. Bol Inst Pesca 2009; 35(1): 91-97.

Ponce-Gordo F, Martínez-Díaz RA. Taxonomía y filogenia del género Entamoeba.: una revisión histórica. Rev Ibero-Latinoam Parasitol 2010; 69(1): 5-37.

Putz RE. Crybtobia cataractae sp. n. (Kinetoplastida: Cryptobiidae), a hemoflagellate of some cyprinid fishes of West Virginia. J Helminthol Soc Wash 1972; 39(1): 18-22.

Pyne CK, Ruch F, Leemann U, Schneider S. Development of the macronuclear anlage in the ciliate Chilodonella uncinate. I. Morphological and cytophotometric studies on the evolution of DNA. Chromosoma 1974; 48(3): 225-238. http://dx.doi.org/10.1007/BF00326506. PMid:4217265

Ranzani-Paiva MJ, Felizardo NN, Luque JL. Parasitological and hematological analysis of Nile tilapia Oreochromis niloticus Linnaeus, 1757 from Guarapiranga reservoir, São Paulo State, Brazil. Acta Sci Biol Sci 2005; 27: 231-237. http://dx.doi.org/10.4025/actascibiolsci.v27i3.1334.

Reed P, Francis-Floyd R. Amyloodinium infections of Marine Fish [online]. Florida: Institute of Food and Agricultural Sciences, University of Florida; 1994 [cited 2014 Jan 30]. VM90. Available from: http://fisheries.tamu. edu/files/2013/09/Amyloodinium-Infections-of-Marine-1195 Fish.pdf.

Robertson DA. A review of Ichthyobodo necator (Henneguy, 1883) an important and damaging fish parasite. In: Muir JF, Roberts RJ, editors. Recent advances in aquaculture. Springer; 1985. p. 1-30.. http://dx.doi. org/10.1007/978-1-4684-8736-7_1.

Roberts-Thomson A, Barnes A, Fielder DS, Lester RJG, Adlard RD. Aerosol dispersal of the fish pathogen, Amyloodinium ocellatum. Aquaculture 2006; 257(1-4): 118-123. http://dx.doi.org/10.1016/j.aquaculture.2006.02.058.

Rothenbacher HJ, Bohl M. Hexamita: pathogenicity and therapy. Fisch und Umwelt 1975; 1: 13-23. [cited 2014 Jan 23]. Available from: http:// www.dfo-mpo.gc.ca/Library/115785.pdf.

Sabry RC, Gesteira TCV, Magalhães ARM, Barracco MA, Guertler C, Ferreira LP, et al. Parasitological survey of mangrove oyster, Crassostrea rhizophorae, in the Pacoti River Estuary, Ceará State, Brazil. J Invertebr Pathol 2013; 112(1): 24-32. http://dx.doi.org/10.1016/j.jip.2012.10.004. PMid:23147104

Sant'Ana FJF, Oliveira SL, Rabelo RE, Vulcani VAS, Silva SMG, Ferreira Junior JA. Surtos de infecção por Piscinoodinium pillulare e Henneguya spp. em pacus (Piaractus mesopotamicus) criados intensivamente no Sudoeste de Goiás. Pesq Vet Bras 2012; 32(2): 121-125. http://dx.doi. org/10.1590/S0100-736X2012000200005.

Santiago H, Corrêa JL, Tortelly R, Menezes RC, Matos P, Matos E. Morphology and histopathology of Calyptospora sp. (Apicomplexa: Calyptosporidae) in speckled peacock bass, Cichla temensis Humboldt, 1821 (Perciformes: Cichlidae), from the Marajó-Açu River, Marajó Island, Brazil. Parasitol Res 2012; 110(6): 2569-2572. http://dx.doi.org/10.1007/ s00436-011-2770-0. PMid:22200958

Saraiva A, Jerónimo D, Cruz C. Amyloodinium ocellatum (Chromalveolata: Dinoflagellata) in farmed turbot. Aquaculture 2011; 320(1-2): 34-36. http://dx.doi.org/10.1016/j.aquaculture.2011.07.034.

Silva WM, Roche KF, Vicente FS, Delben AAST. First record of the peritrich Trichodina diaptomi Basson and Van As, 1991 (Protozoa: Ciliophora) on a South American calanoid Notodiaptomus deitersi (Poppe, 1890) (Crustacea: Copepoda). J Eukaryot Microbiol 2009; 56(4): 385. http://dx.doi.org/10.1111/j.1550-7408.2009.00414.x. PMid:19602084 
Silva MC, São Clemente SC, Picanço Júnior JA, Silva MVO, Matos ER. Calyptospora sp. in Brachyplatystoma vaillantii trapped at the Vigia, State of Pará, Brazil. Rev Bras Parasitol Vet 2012; 21(2): 176-178. PMid:22832762.

Tavares-Dias M, Lemos JRG, Martins ML, Jerônimo GT. Metazoan and protozoan parasites of freshwater ornamental fish from Brazil. In: Tavares-Dias M, editor. Manejo e sanidade de peixes em cultivo. Macapá: Embrapa Amapá; 2009. p. 469-494. cap. 19.

Tavares-Dias M, Lemos JRG, Martins ML. Parasitic fauna of eight species of ornamental freshwater fish species from the middle Negro River in the Brazilian Amazon Region. Rev Bras Parasitol Vet 2010; 19(2): 103-107. http://dx.doi.org/10.4322/rbpv.01902007. PMid:20624347

Thatcher VE. Amazon fish parasites. Sofia: Pensoft Publishers; 2006.

Todal JA, Karlsbakk E, Isaksen TE, Plarre H, Urawa S, Mouton A, et al. Ichthyobodo necator (Kinetoplastida) - a complex of sibling species. Dis Aquat Organ 2004; 58(1): 9-16. http://dx.doi.org/10.3354/dao058009. PMid:15038446

Urawa S, Ueki N, Nakai T, Yamasaki H. High mortality of cultured juvenile Japanese flounder, Paralichthys olivaceus (Temminek \& Sehlegel), caused by the parasitic flagellate Ichthyobodo sp. J Fish Dis 1991; 14(4): 489-494. http://dx.doi.org/10.1111/j.1365-2761.1991.tb00602.x.

Valladão GMR, Pádua SB, Gallani SU, Menezes-Filho RN, Dias-Neto J, Martins ML, et al. Paratrichodina africana (Ciliophora): a pathogenic gill parasite in farmed Nile tilapia. Vet Parasitol 2013; 197(3-4): 705710. http://dx.doi.org/10.1016/j.vetpar.2013.04.043. PMid:23731856

Valladão GMR, Gallani SU, Pádua SB, Martins ML, Pilarski F. Trichodina heterodentata (Ciliophora) infestation on Prochilodus lineatus larvae: a host-parasite relationship study. Parasitology 2014; 141(5): 662-669. http://dx.doi.org/10.1017/S0031182013001480. PMid:24476792

Van As JG, Basson L. A further contribution to the taxonomy of the Trichodinidae (Ciliophora: Peritrichia) and a review of the taxonomic status of some fish ectoparasitic trichodinids. Syst Parasitol 1989; 14(3): 157-179. http://dx.doi.org/10.1007/BF02187051.
Visse M. Detrimental effect of peritrich ciliates (Epistylis sp.) as epibionts on the survival of the copepod Acartia bifilosa. Proc Estonian Acad Sci Biol Ecol 2007; 56(3): 173-178.

Woo PTK. The haematocrit centrifuge for the detection of trypanosomes in blood. Can J Zool 1969; 47(5): 921-923. http://dx.doi.org/10.1139/ z69-150. PMid:5343381

Woo PTK. Diplomonadida (Phylum Parabasalia) and Kinetoplastea (Phylum Euglenozoa). In: Woo PTK, editor. Fish diseases and disorders. 2nd ed. Wallingford: CABI Publishing, 2006. p. 116-153. cap. 4. vol. 1. Protozoan and Metazoan infections. http://dx.doi.org/10.1079/978 0851990156.0046

Woo PTK. Protective immunity in fish against protozoan diseases. Parassitologia 2007; 49(3): 185-191. PMid:18410078.

Woo PTK, Ardelli BF. Immunity against selected piscine flagellates. Dev Comp Immunol 2014; 43(2): 268-279. http://dx.doi.org/10.1016/j. dci.2013.07.006. PMid:23872230

$\mathrm{Xu}$ D-H, Klesius PH. Two year study on the infectivity of Ichthyophthirius multifiliis in channel catfish Ictalurus punctatus. Dis Aquat Organ 2004; 59(2): 131-134. http://dx.doi.org/10.3354/dao059131. PMid:15212279

$\mathrm{Xu}$ D-H, Klesius PH, Shoemaker CA. Evaluation of a cohabitation challenge model in immunization trials for channel catfish Ictalurus punctatus against Ichthyophthirius multifiliis. Dis Aquat Organ 2007; 74(1): 49-55. http://dx.doi.org/10.3354/dao074049. PMid:17425263

Xu D-H, Shoemaker CA, Martins ML, Pridgeon JW, Klesius PH. Enhanced susceptibility of channel catfish to the bacterium Edwardsiella ictaluri after parasitism by Ichthyophthirius multifliis. Vet Microbiol 2012; 158(1-2): 216-219. http://dx.doi.org/10.1016/j.vetmic.2012.02.007. PMid:22397934

Yemmen C, Ktari MH, Bahri S. Seasonality and histopathology of Trichodina puytoraci Lom, 1962, a parasite of flathead mullet (Mugil cephalus) from Tunisia. Acta Adriat 2011; 52(1): 15-20. 